\title{
Global modeling of secondary organic aerosol formation from aromatic hydrocarbons: high- vs. low-yield pathways
}

\author{
D. K. Henze ${ }^{1, *}$, J. H. Seinfeld ${ }^{1}$, N. L. Ng ${ }^{1}$, J. H. Kroll ${ }^{2}$, T.-M. Fu ${ }^{3}{ }^{* *}$, D. J. Jacob ${ }^{3}$, and C. L. Heald ${ }^{4, * * *}$ \\ ${ }^{1}$ Department of Chemical Engineering, California Institute of Technology, Pasadena, California, USA \\ ${ }^{2}$ Aerodyne Research, Inc., Billerica, Massachusetts, USA \\ ${ }^{3}$ School of Engineering and Applied Sciences and Department of Earth and Planetary Sciences, Harvard University, \\ Cambridge, Massachusetts, USA \\ ${ }^{4}$ Center for Atmospheric Sciences, University of California, Berkeley, California, USA \\ * now at: NASA Goddard Institute for Space Studies and the Earth Institute, Columbia University, New York, New York, USA \\ ** now at: Department of Civil and Structural Engineering, The Hong Kong Polytechnic University, Hung Hom, Kowloon, \\ Hong Kong,China \\ **** now at: Department for Atmospheric Science, Colorado State University, Fort Collins, Colorado, USA
}

Received: 1 August 2007 - Published in Atmos. Chem. Phys. Discuss.: 15 October 2007

Revised: 11 January 2008 - Accepted: 21 February 2008 - Published: 7 May 2008

\begin{abstract}
Formation of SOA from the aromatic species toluene, xylene, and, for the first time, benzene, is added to a global chemical transport model. A simple mechanism is presented that accounts for competition between low and high-yield pathways of SOA formation, wherein secondary gas-phase products react further with either nitric oxide (NO) or hydroperoxy radical $\left(\mathrm{HO}_{2}\right)$ to yield semi- or non-volatile products, respectively. Aromatic species yield more SOA when they react with $\mathrm{OH}$ in regions where the $[\mathrm{NO}] /\left[\mathrm{HO}_{2}\right]$ ratios are lower. The SOA yield thus depends upon the distribution of aromatic emissions, with biomass burning emissions being in areas with lower $[\mathrm{NO}] /\left[\mathrm{HO}_{2}\right]$ ratios, and the reactivity of the aromatic with respect to $\mathrm{OH}$, as a lower initial reactivity allows transport away from industrial source regions, where $[\mathrm{NO}] /\left[\mathrm{HO}_{2}\right]$ ratios are higher, to more remote regions, where this ratio is lower and, hence, the ultimate yield of SOA is higher. As a result, benzene is estimated to be the most important aromatic species with regards to global formation of SOA, with a total production nearly equal that of toluene and xylene combined. Global production of SOA from aromatic sources via the mechanisms identified here is estimated at $3.5 \mathrm{Tg} / \mathrm{yr}$, resulting in a global burden of $0.08 \mathrm{Tg}$, twice as large as previous estimates. The contribution of these largely anthropogenic sources to global SOA is still small relative to biogenic sources, which are estimated to comprise $90 \%$ of the global SOA burden, about half of which comes from isoprene. Uncertainty in these es-
\end{abstract}

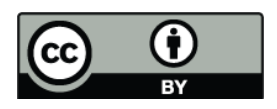

Correspondence to: D. K. Henze (dkh2114@columbia.edu) timates owing to factors ranging from the atmospheric relevance of chamber conditions to model deficiencies result in an estimated range of SOA production from aromatics of $2-12 \mathrm{Tg} / \mathrm{yr}$. Though this uncertainty range affords a significant anthropogenic contribution to global SOA, it is evident from comparisons to recent observations that additional pathways for production of anthropogenic SOA still exist beyond those accounted for here. Nevertheless, owing to differences in spatial distributions of sources and seasons of peak production, regions exist in which aromatic SOA produced via the mechanisms identified here are predicted to contribute substantially to, and even dominate, the local SOA concentrations, such as outflow regions from North America and South East Asia during the wintertime, though total modeled SOA concentrations there are small $\left(\sim 0.1 \mu \mathrm{g} / \mathrm{m}^{3}\right)$.

\section{Introduction}

Organic aerosols play an important role in global climate (Kanakidou et al., 2005). A significant fraction of organic aerosol material results from the physical and chemical processing of volatile gas-phase hydrocarbons to yield less volatile products that condense in the particulate phase; this is referred to as secondary organic aerosol (SOA). At present, levels of organic aerosol measured in field campaigns tend to exceed those predicted by global chemical transport models (Heald et al., 2005, 2006). While it is predicted that, on the global scale, secondary organic aerosol from biogenic sources substantially exceeds that from anthropogenic sources (Tsigaridis et al., 2006; Tsigaridis and Kanakidou,

Published by Copernicus Publications on behalf of the European Geosciences Union. 
2007), data from recent field studies suggest that SOA from anthropogenic hydrocarbons might be more significant than previously thought (de Gouw et al., 2005; Volkamer et al., 2006; Kleinman et al., 2007; de Gouw et al., 2008).

Among anthropogenic hydrocarbons, aromatic compounds have been traditionally considered to be the most important SOA precursors. It has recently been established that the SOA yields (aerosol yield is defined as the ratio of the mass of organic aerosol produced to the mass of parent hydrocarbon reacted) from aromatics, as well as those from a variety of other hydrocarbons, depend critically on the prevailing level of nitrogen oxides $\left(\mathrm{NO}_{\mathrm{x}}\right)$ (Hurley et al., 2001; Martin-Reviejo and Wirtz, 2005; Presto et al., 2005; Song et al., 2005; Johnson et al., 2004, 2005; Ng et al., 2007; Song et al., 2007). This discovery led to a systematic re-evaluation of aromatic SOA yields ( $\mathrm{Ng}$ et al., 2007) from the historical yields of Odum et al. $(1996,1997)$ that were measured under high- $\mathrm{NO}_{\mathrm{x}}$ conditions. In particular, aromatic yields under the low- $\mathrm{NO}_{\mathrm{x}}$ conditions typical of most of the global atmosphere significantly exceed those under high- $\mathrm{NO}_{\mathrm{x}}$ conditions typical of urban cores (and of past laboratory chamber experiments). However, given that sources of aromatics are likely co-located with sources of $\mathrm{NO}_{\mathrm{x}}$, the significance of this finding on the global SOA burden is not readily apparent.

Initial global modeling studies of SOA formation from toluene and xylene (Tsigaridis and Kanakidou, 2003) used the empirical yield parameters from Odum et al. (1996, 1997). More recently (Tsigaridis et al., 2006), this model was updated to include the $\mathrm{NO}_{\mathrm{x}}$ dependence of yields for toluene and xylene based upon the xylene yields in the work of Song et al. (2005). Lack et al. (2004) also included aromatic species in their lumped calculation of SOA formation from industrial sources, using yield coefficients from Odum et al. (1997) and Cocker et al. (2001). SOA formation from benzene, as identified by Martin-Reviejo and Wirtz (2005), has been noted to be an important additional pathway in the box model studies of Pun and Seigneur (2007) and the Lagrangian trajectory model of Johnson et al. (2006). The recent data ( $\mathrm{Ng}$ et al., 2007) on SOA yields from all of these aromatic hydrocarbons prompt a re-evaluation of the contribution of aromatic SOA to the global SOA production rate and burden. In the current study, the GEOS-Chem global chemical transport model is updated to include abbreviated aromatic oxidation chemistry and SOA formation from aromatics.

\section{Summary of SOA yields from aromatic hydrocarbons}

The SOA-forming potentials of $m$-xylene, toluene, and benzene have been measured in a series of laboratory chamber experiments ( $\mathrm{Ng}$ et al., 2007). Atmospheric reaction of these aromatics with the hydroxyl radical $(\mathrm{OH})$ initiates a complex series of gas-phase reactions (Calvert et al., 2002; Koch et al., 2007). As noted above, a crucial factor governing the nature of the gas-phase chemistry and subsequent aerosol formation is the $\mathrm{NO}_{\mathrm{x}}$ level. Experiments were conducted under both low- and high- $\mathrm{NO}_{\mathrm{x}}$ conditions; these correspond to $\mathrm{NO}_{\mathrm{x}}$ levels of less than 1 parts-per-billion by volume (ppb) and several hundred ppb, respectively.

SOA yields of the three aromatics studied are highly dependent on the prevailing $\mathrm{NO}_{\mathrm{x}}$ level. Under high- $\mathrm{NO}_{\mathrm{x}}$ conditions, measured yields for toluene and $m$-xylene are in the range of 5 to $10 \%$ with a strong dependence on the amount of organic aerosol present, in general agreement with those reported by Odum et al. $(1996,1997)$. Under low- $\mathrm{NO}_{\mathrm{x}}$ conditions, all three compounds exhibit high $(\geqslant 30 \%)$ constant yields, exceeding yields from high- $\mathrm{NO}_{\mathrm{x}}$ conditions. Similar findings for SOA yields from $m$-xylene have been reported by Song et al. (2007). The first studies of SOA yields from benzene reported overall yields in the range of 6$14 \%$ for both high and low- $\mathrm{NO}_{\mathrm{x}}$ conditions (Martin-Reviejo and Wirtz, 2005); $\mathrm{Ng}$ et al. (2007) found a considerably higher yield for benzene, $28 \%$ and $37 \%$ under high- and low$\mathrm{NO}_{\mathrm{x}}$ conditions, respectively. The discrepancies between the two studies, particularly between the two reported low- $\mathrm{NO}_{\mathrm{x}}$ yields in Martin-Reviejo and Wirtz (2005) and the one yield in $\mathrm{Ng}$ et al. (2007), may be a result of higher SOA yields in the presence of an inorganic seed in the experiments of $\mathrm{Ng}$ et al. (2007). Additional factors, such as the uncertainty in the benzene threshold concentrations in Martin-Reviejo and Wirtz (2005) make comparisons between these results difficult. While further studies of the low- $\mathrm{NO}_{\mathrm{x}}$ yields of benzene are clearly called for, use of inorganic seed particles in $\mathrm{Ng}$ et al. (2007) affords partial decoupling of the $\mathrm{NO}_{\mathrm{x}}$ effect from the effects of an "induction period" caused by the absence of preexisting organic aerosol (Kroll et al., 2007), which will be shown to facilitate use of such data for modeling SOA formation.

The mechanisms for atmospheric oxidation of both biogenic and anthropogenic hydrocarbons are complex and not fully understood; it does appear, however, that the observed low- and high- $\mathrm{NO}_{\mathrm{x}}$ behavior of SOA formation (Song et al., 2005; $\mathrm{Ng}$ et al., 2007) hinges on the competitive reactions of the bicyclic peroxy radicals $\left(\mathrm{RO}_{2}\right)$ that result from initial attack of the aromatic species by $\mathrm{OH}$ radicals followed quickly by $\mathrm{O}_{2}$ addition and cyclization (Johnson et al., 2005; Koch et al., 2007), written here simply as

$$
\begin{aligned}
& \text { aromatic } \stackrel{k_{\mathrm{OH}}}{\longrightarrow} \text { aromatic }-\mathrm{OH} \text { adduct } \stackrel{\mathrm{O}_{2}}{\rightleftharpoons} \\
& \text { aromatic }-\mathrm{OH}-\mathrm{O}_{2} \text { peroxy radical } \\
& \text { Isomerization, } \mathrm{O}_{2} \text { bicyclic peroxy radical }
\end{aligned}
$$

As explained in detail in $\mathrm{Ng}$ et al. (2007), the alternative reaction of the aromatic-OH adducts with $\mathrm{NO}_{2}$ is not expected to play a significant role under chamber conditions (Koch et al., 2007). It has been shown that high ( $>100 \mathrm{ppb}$ ) levels of $\mathrm{NO}_{\mathrm{x}}$ affect the fate of the aromatic-OH- $\mathrm{O}_{2}$ peroxy radicals (Volkamer et al., 2002; Klotz et al., 2002; Volkamer et al., 2002b) 
Table 1. Stoichiometric coefficients, $\alpha_{i, j}$, and equilibrium partitioning coefficients, $K_{i, j}$, for SOA formation derived from high and low-NO chamber experiments of reaction of aromatics with $\mathrm{OH}\left(\mathrm{Ng}\right.$ et al., 2007). The reference temperature for the $K_{i, j}$ 's is $295 \mathrm{~K}$.

\begin{tabular}{lccccc}
\hline Parent aromatic $i$ & $\alpha_{i, H}$ & $\alpha_{i, 1}$ & $\alpha_{i, 2}$ & $\begin{array}{c}K_{i, 1} \\
{\left[\mathrm{~m}^{3} \mu \mathrm{g}^{-1}\right]}\end{array}$ & $\begin{array}{c}K_{i, 2} \\
{\left[\mathrm{~m}^{3} \mu \mathrm{g}^{-1}\right]}\end{array}$ \\
\hline benzene & 0.1815 & 0.0353 & 0.4356 & 3.3150 & 0.0090 \\
toluene & 0.1914 & 0.0308 & 0.0601 & 0.4300 & 0.0470 \\
$m$-xylene & 0.1701 & 0.0176 & 0.0510 & 0.7610 & 0.0290 \\
\hline
\end{tabular}

as evident from phenol yields (the phenol products form via an alternative fate of the aromatic-OH- $\mathrm{O}_{2}$ species - loss of $\mathrm{HO}_{2}$ ). The high $\mathrm{NO}_{\mathrm{x}}$ benzene oxidation experiments of $\mathrm{Ng}$ et al. (2007) were hence carried out with initial $\mathrm{NO}_{2}$ levels $<100 \mathrm{ppb}$. Theoretical studies of $p$ - and $m$-xylene oxidation suggest that levels of NO up to ppm do not prevent formation of bicyclic peroxy radicals from the aromatic-OH-O $\mathrm{O}_{2}$ peroxy radicals after isomerization and $\mathrm{O}_{2}$ addition (Zhao et al., 2005; Fan and Zhang, 2006), though formation of the phenol product was not considered. Assuming that these theoretical results are applicable to toluene as well, it seems likely that deviation from the isomerization pathway of (R1) was not the main influence of $\mathrm{NO}$ for the aromatic oxidation studies of $\mathrm{Ng}$ et al. (2007). However, a lack of a complete characterization of the influence of $\mathrm{NO}_{\mathrm{x}}$ reactions on aromatic oxidation represents a source of uncertainty in this assumption and in extrapolating these SOA yields from chamber conditions to different $\mathrm{NO}_{\mathrm{x}}$ levels. The bicyclic peroxy radicals react predominantly with either hydroperoxy radicals $\left(\mathrm{HO}_{2}\right)$ or $\mathrm{NO}$, depending on the relative concentrations of $\mathrm{HO}_{2}$ and NO. Reaction of these peroxy radicals with themselves is found to be unimportant under chamber conditions (the rate constant for this reaction is relatively small and $\mathrm{HO}_{2}$ concentrations are high) in the kinetic simulations of $\mathrm{Ng}$ et al. (2007). The role of such competing reactions in the atmosphere is assessed later in the present work.

While it is common to refer to the oxidative conditions in environmental chambers according to absolute $\mathrm{NO}_{\mathrm{x}}$ levels or VOC: $\mathrm{NO}_{\mathrm{x}}$ ratios (as those are typically what is measured), it is often the ratio of $[\mathrm{NO}] /\left[\mathrm{HO}_{2}\right]$ that determines the fate of secondary gas-phase products and which is more important than absolute $\mathrm{NO}_{\mathrm{x}}$ concentrations for extrapolating results from environmental chamber conditions to atmospheric conditions. Under low- $\mathrm{NO}_{\mathrm{x}}$ conditions, the levels of $\mathrm{HO}_{2}$ radical in the chamber are such that reaction with $\mathrm{HO}_{2}$ radical is favored, and the resulting products, including hydroperoxides, are generally less volatile than those that result from the NO reaction path. This competition can be represented as follows:

$$
\begin{aligned}
\mathrm{RO}_{2}+\mathrm{HO}_{2} \stackrel{k_{H}}{\longrightarrow} & \alpha_{H} \mathrm{SOG}_{H}+\cdots \\
\mathrm{RO}_{2}+\mathrm{NO} \stackrel{k_{N}}{\longrightarrow} & \alpha_{1} \mathrm{SOG}_{1}+\alpha_{2} \mathrm{SOG}_{2}+\cdots
\end{aligned}
$$

where $\mathrm{RO}_{2}$ are the bicyclic peroxy radicals from (R1), SOG designates secondary organic gas-phase semivolatile products, and the $\alpha$ 's are mass-based stoichiometric coefficients (i.e. for every gram of peroxy radical that reacts, $\alpha$ grams of SOG are formed).

The fact that, for all three aromatics, the SOA yield under low- $\mathrm{NO}_{\mathrm{x}}$ conditions is constant with respect to changes in available substrate implies that the semivolatile products are essentially nonvolatile, at least at the level of aerosol mass concentrations in the chamber; thus, the $\mathrm{RO}_{2}+\mathrm{HO}_{2}$ pathway can be represented as leading to a single nonvolatile product, $\mathrm{SOG}_{\mathrm{H}}=\mathrm{SOA}_{\mathrm{H}}$. Since the high-NO pathway exhibits yields that depend on the total amount of absorbing organic aerosol, we use the customary two-product model for SOA formation, originally formulated by Odum et al. (1996, 1997); SOG 1 and $\mathrm{SOG}_{2}$ represent these products, which have associated gas-particle partitioning equilibrium constants, $K_{1}$ and $K_{2}$,

$\left[\mathrm{SOG}_{i}\right]=\frac{\left[\mathrm{SOA}_{i}\right]}{K_{i} M}$,

where $M$ is the concentration of total available substrate in $\mu \mathrm{g} \mathrm{m}^{-3}$. Parameters describing yields under both sets of $\mathrm{NO}_{\mathrm{x}}$ levels are given in Table 1. Equilibrium constants and stoichiometric coefficients are based on laboratory studies of $\mathrm{Ng}$ et al. (2007), where here the latter are multiplied by the ratio of the molecular weight of the parent aromatic to that of the peroxy radical to reflect formation of SOG species directly from the peroxy radical. The assumption that the low$\mathrm{NO}_{\mathrm{x}}$ product is nonvolatile is specific to aromatic species; in general, sets of $\alpha$ 's and $K$ 's can be derived for semivolatile products from both pathways.

\section{Aromatic SOA formation in GEOS-Chem}

In the current study, the GEOS-Chem global chemical transport model (version 7-04-11 with a horizontal resolution of $2^{\circ} \times 2.5^{\circ}$ and 30 layers up to $0.01 \mathrm{hPa}$, GEOS-4 meteorological fields) is used to simulate one year of present day conditions (2004). This model includes detailed simulation of gasphase tropospheric chemistry (e.g., Bey et al., 2001; Hudman et al., 2007) in addition to external mixtures of several aerosol components (Park et al., 2004, 2006). Previous versions have been implemented with a gas-particle partitioning 
(a) Benzene, 5.6 Tg C/yr

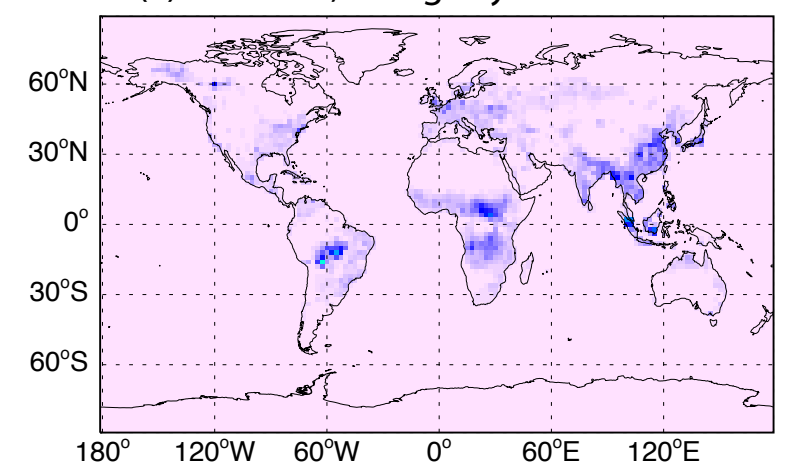

(c) Xylene, $4.7 \mathrm{Tg} \mathrm{C} / \mathrm{yr}$

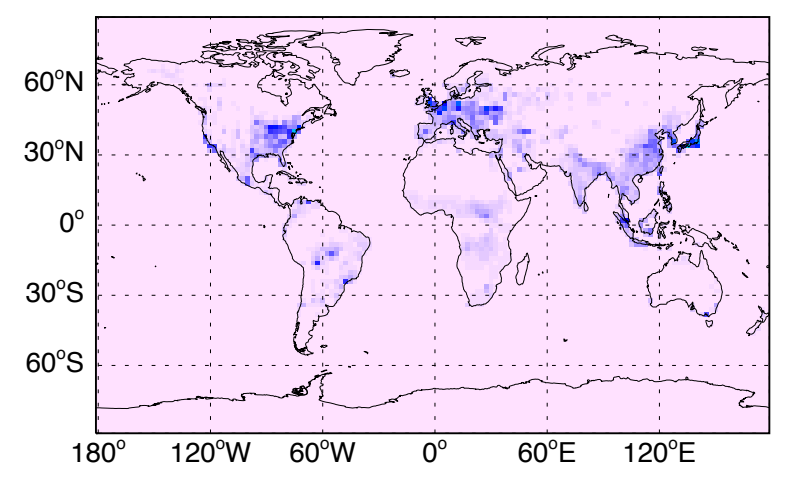

(b) Toluene, 6.9 Tg C/yr

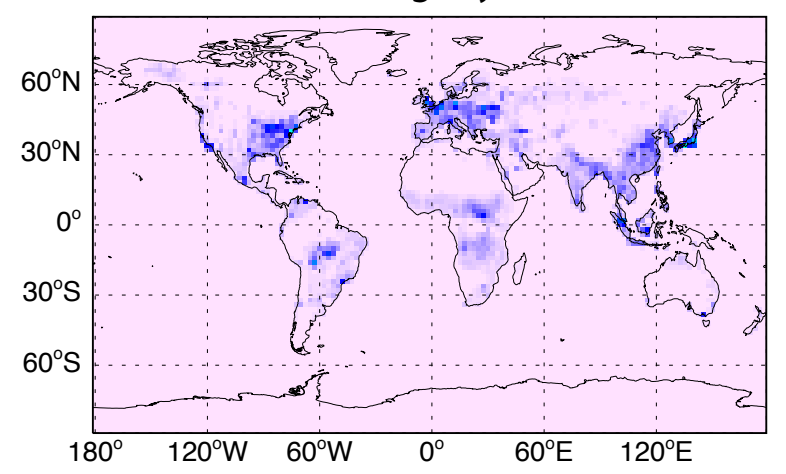

(d) Total, 17.2 Tg C/yr

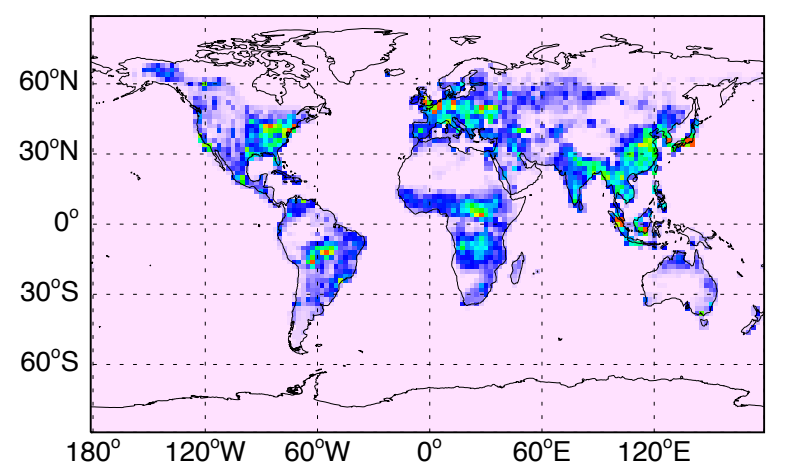

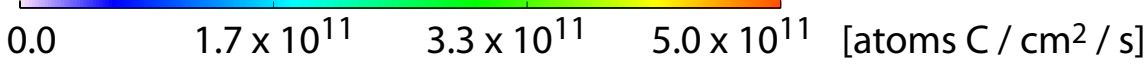

Fig. 1. Emissions of aromatic compounds.

Table 2. Reaction rate constants, $k=A e^{B / T}$.

\begin{tabular}{lcccc}
\hline Reaction & Rate constant $^{\mathrm{a}}$ & $\begin{array}{c}k_{298} \\
{\left[\mathrm{~cm}^{3} \mathrm{molec}^{-1} \mathrm{~s}^{-1}\right]}\end{array}$ & $\begin{array}{c}A \\
{\left[\mathrm{~cm}^{3} \mathrm{molec}^{-1} \mathrm{~s}^{-1}\right]}\end{array}$ & $\begin{array}{c}B \\
{[\mathrm{~K}]}\end{array}$ \\
\hline$(\mathrm{R} 1)$ & $k_{O H, B}$ & $1.22 \times 10^{-12}$ & $2.33 \times 10^{-12}$ & -193 \\
$(\mathrm{R} 1)$ & $k_{O H, T}$ & $5.63 \times 10^{-12}$ & $1.81 \times 10^{-12}$ & 338 \\
$(\mathrm{R} 1)$ & $k_{O H, X}$ & $2.31 \times 10^{-11}$ & $2.31 \times 10^{-11}$ & 0 \\
$(\mathrm{R} 2)$ & $k_{H}$ & $1.5 \times 10^{-11}$ & $1.4 \times 10^{-12}$ & 700 \\
$(\mathrm{R} 3)$ & $k_{N}$ & $8.5 \times 10^{-12}$ & $2.6 \times 10^{-12}$ & 350 \\
\hline
\end{tabular}

${ }^{\text {a }} B=$ benzene, $T=$ toluene, $X=$ xylene. Constants $k_{\mathrm{H}}$ and $k_{\mathrm{N}}$ assumed equal for each parent aromatic.

model of SOA formation from terpenes, alcohols, sesquiterpenes (Chung and Seinfeld, 2002; Heald et al., 2005) and isoprene (Henze and Seinfeld, 2006). As such, estimates of organic carbon aerosol have been notably low compared to measurements during springtime 2001 measurements in the free troposphere of the Asian continental outflow re- gion (ACE-Asia) (Heald et al., 2005) and have failed to capture the variance in observations in the free troposphere during the summer 2004 campaign (ICARTT) in the northeastern United States (Heald et al., 2006); in comparison, such overwhelming inconsistencies have not been found in yearly average estimates of surface organic aerosol concentrations 
compared to filter samples (Liao et al., 2007). The addition of abbreviated aromatic oxidation chemistry and SOA formation from aromatics to the chemical reactions and SOA module in GEOS-Chem is described in the following sections.

\subsection{Global emissions}

Global emissions of benzene, toluene and xylene from industrial and fossil fuel sources are taken from the Emission Database for Global Atmospheric Research (EDGAR V2.0) (Olivier et al., 1996, 1999) for 1990 and scaled to the year 2000 using liquid fossil fuel usage from the Global Emission Inventory Activity (GEIA) project (Benkovitz et al., 1996) following Bey et al. (2001). Emissions of aromatics from biofuel and biomass burning are calculated by applying emission ratios to emissions of $\mathrm{CO}$, where sources of $\mathrm{CO}$ from biofuel burning are from the GEIA database, while biomass burning sources of $\mathrm{CO}$ are from the Global Fire Emissions Database version 2 (GFEDv2) (Giglio et al., 2006; van der Werf et al., 2006). The emissions ratios, listed in Table 3, are taken from Andreae and Merlet (2001) with updates from Andreae (personal communication, 2006). Total emissions are 5.6, 6.9 and $4.7 \mathrm{Tg} \mathrm{C} / \mathrm{yr}$ for benzene, toluene and $\mathrm{xy}-$ lene, respectively. The breakdown by source type is given in Table 4, and the yearly average emission fluxes of each aromatic species, and the combined total, are shown in Fig. 1. The largest global sources are road transport and solvent use (for toluene and xylene), and biofuel and biomass burning (for benzene); road transport is the main source of benzene in urban areas. Anthropogenic emissions dominate in northern mid-latitudes, which are thus fairly aseasonal, while biomass burning is a major source in the Southern Hemisphere with strong seasonal cycles.

Fossil fuel $\mathrm{NO}_{\mathrm{x}}$ emissions are from the GEIA inventory and are scaled to year 2001 using liquid fossil fuel usage Bey et al. (2001). The biomass burning $\mathrm{NO}_{\mathrm{x}}$ emissions are from GFEDv2, and additional sources of $\mathrm{NO}_{\mathrm{x}}$ emissions from biofuel, lightning, soil and ships are as described in Martin et al. (2002). Isoprene and monoterpene emissions are calculated using the MEGAN (Model of Emissions of Gases and Aerosols from Nature) version 2 model (Guenther et al., 2006), totaling 408 and $103 \mathrm{Tg} \mathrm{C} / \mathrm{yr}$, respectively, while primary organic aerosol emissions are $9.8 \mathrm{Tg} \mathrm{C} / \mathrm{yr}$ from anthropogenic fuel sources following Park et al. (2006) and 23.3 Tg C/yr from GFEDv2.

\subsection{Implementation of aromatic SOA formation}

Gas-phase oxidation of each parent aromatic hydrocarbon (1) and subsequent reaction of the peroxy radical product, $\mathrm{RO}_{2}$, with $\mathrm{HO}_{2}$ (2) and $\mathrm{NO}(3)$ is calculated online as an additional part of the tropospheric chemical reaction mechanism. The loss of $\mathrm{RO}_{2}$ via each reaction is tracked in order to explicitly calculate the branching ratio between these two pathways; this implementation allows natural transitions between
Table 3. Emission ratios for biofuel and biomass burning sources of aromatic species (mmoles emitted per mole CO emitted) taken from Andreae and Merlet (2001) with updates from Andreae (personal communication, 2006).

\begin{tabular}{lcc}
\hline Aromatic species & Biofuel burning & Biomass burning \\
\hline benzene & 4.06 & 2.33 \\
toluene & 2.01 & 1.24 \\
xylene & 0.82 & 0.48 \\
\hline
\end{tabular}

low and high-yield environments as governed by temperature, and $\mathrm{HO}_{2}$ radical and $\mathrm{NO}$ concentrations. This approach, initially suggested in the work of Presto and Donahue (2006), has the advantage of avoiding prior delineation of oxidative regimes based upon $\mathrm{VOC} / \mathrm{NO}_{\mathrm{x}}$ ratios (Song et al., 2005; Tsigaridis et al., 2006; Presto and Donahue, 2006). Parameters for calculating the reaction rate constants for these steps are listed in Table 2. Kinetic parameters for reaction of the aromatic species with $\mathrm{OH}$ (the rate limiting step in peroxy radical formation) are from Calvert et al. (2002). Rate constants for peroxy radical reactions, (2) and (3), are from Atkinson et al. (1997), assuming similar temperature dependence as peroxy radical reactions with isoprene, as most reactions of hydrocarbon peroxy radicals with $\mathrm{NO}$ and $\mathrm{HO}_{2}$ have similar kinetics (Lightfoot et al., 1992; Eberhard and Howard, 1997). All forms of xylene are assumed to behave as $m$-xylene for both gas and aerosol processes.

Calculation of reversible SOA formation follows the approach outlined in Chung and Seinfeld (2002). The empirical yield parameters (Table 1) are used to estimate the mass of SOA formed per mass of peroxy radical that reacts. An important aspect of this treatment is specification of the available substrate, $M$, which affects gas-particle equilibrium. For this work, $M$ is taken to consist of the total mass of primary and secondary organic material ${ }^{1}$. As GEOS-Chem tracks only the carbonaceous component of primary organic aerosol, the ratio of total organic to organic carbon aerosol mass must be specified in order to calculate $M$ - here the ratio is assumed to be 2.1. Though this differs from previous studies that used a ratio of 1.4 (Henze and Seinfeld, 2006; Liao et al., 2007; Heald et al., 2006; Zhang et al., 2007; van Donkelaar et al., 2007), 2.1 is recommended for nonurban aerosols (Turpin and Lim, 2001). Given the ubiquity of highly oxygenated carbonaceous aerosol in urban and remote areas (Zhang et al., 2007) and that $M$ represents both primary and secondary organic aerosol mass, the higher ratio is thought to better represent the bulk properties of global organic aerosol. The Clausius-Clapeyron equation is used to extrapolate equilibrium constants to tropospheric tempera-

\footnotetext{
${ }^{1}$ Condensation directly on sulfate aerosol, considered in some versions of GEOS-Chem and other studies (Tsigaridis and Kanakidou, 2003), is not included in these simulations.
} 
Table 4. Emissions of each aromatic species broken down by source [Tg C/yr].

\begin{tabular}{lccc}
\hline Aromatic species & Industrial and fossil fuel & Biofuel burning & Biomass burning \\
\hline benzene & 1.3 & 1.8 & 2.5 \\
toluene & 4.3 & 1.0 & 1.6 \\
xylene & 3.5 & 0.5 & 0.7 \\
\hline
\end{tabular}
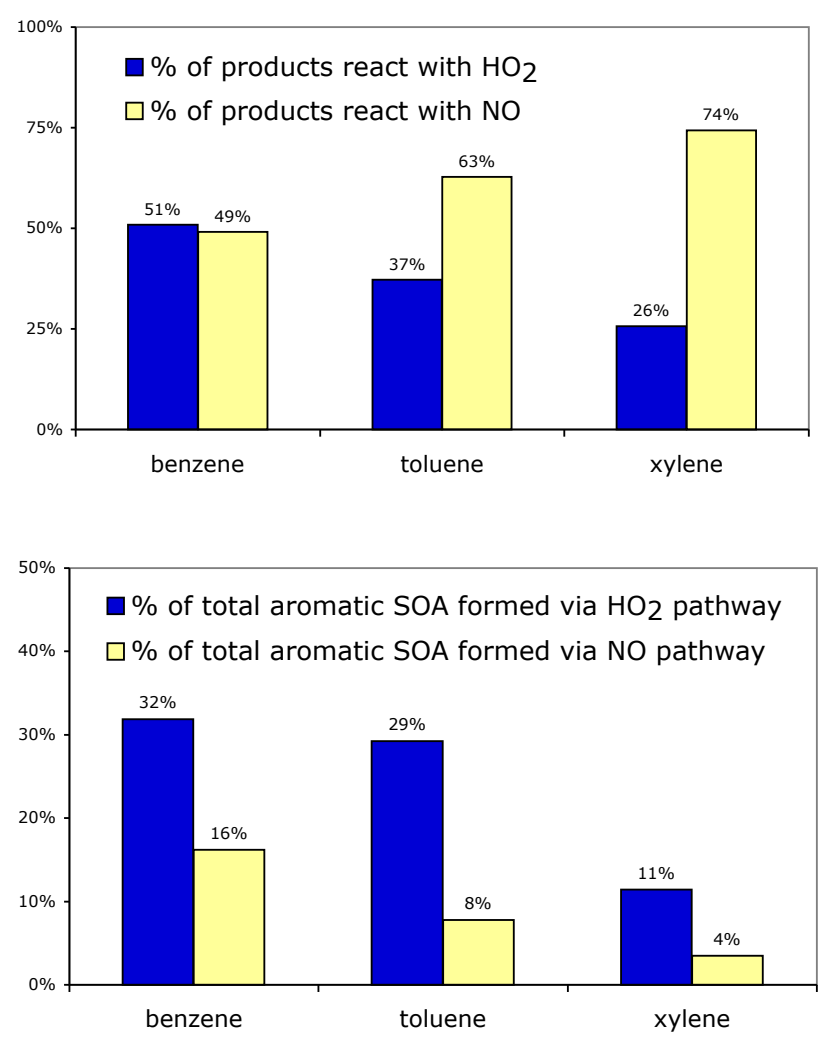

Fig. 2. Percentages of peroxy radical from each parent aromatic that react with $\mathrm{HO}_{2}$ radical (2) vs. with $\mathrm{NO}$ (3) and the eventual contributions from each pathway to the total SOA production from all aromatic species.

tures. The enthalpy of vaporization for SOA is assumed to be $42 \mathrm{~kJ} \mathrm{~mol}^{-1}$ for all species, in the range of limited available experimental data (Offenberg et al., 2006). Dry deposition of all types of SOA is calculated using a resistance-in-series model (Wesely, 1989; Wang et al., 1998); wet scavenging follows Liu et al. (2001) with an assumed scavenging efficiency of $80 \%$ (Chung and Seinfeld, 2002).

\section{Simulation of global aromatic SOA}

The predicted contributions of benzene, toluene, and xylene to global aromatic SOA via high- and low-yield pathways (the opposite of the $\mathrm{NO}_{\mathrm{x}}$ levels) and the percentage of the aromatics that react via each pathway are given in Fig. 2.
Thus, $51 \%$ of globally emitted benzene, for example, reacts via reaction (2), the high-yield path, whereas only $26 \%$ of xylene follows this route. The location of the sources plays an important role in determining the total SOA yield from each species. Aromatics, primarily benzene, emitted from biofuel and biomass burning sources are more likely to react via the high-yield pathway as these emissions are less associated with sources of $\mathrm{NO}_{\mathrm{x}}$ than the industrial and fossil fuel emissions. Additionally, for emissions from industrial and fossil fuel sources, it is the less reactive aromatics, as measured by their $\mathrm{OH}$ reaction rate constants, that actually produce more SOA. The explanation is that lower reactivity affords the parent hydrocarbon more time to be transported to regions of lower $[\mathrm{NO}] /\left[\mathrm{HO}_{2}\right]$ ratios, where ultimately, once reacted, the SOA yield is larger. Proportionately more of a reactive molecule like xylene is consumed in regions in which the $\mathrm{NO}_{\mathrm{x}}$ levels are more characteristic of the source emission areas. On a global average, 39\% of the total aromatics proceed through the high yield pathway. As a result, $72 \%$ of global aromatic SOA is produced via the high-yield (low- $\mathrm{NO}_{\mathrm{x}}$ ) pathway.

Figure 3 shows the predicted seasonally averaged surfacelevel concentrations of aromatic SOA. The concentrations generally reflect the distribution of areas with substantial anthropogenic emissions in northern mid-latitudes, which are themselves aseasonal, and biomass burning in the Southern Hemisphere, which have strong seasonal cycles. The resulting SOA concentrations show considerable seasonal variability, even in the northern mid-latitudes. Concentrations in the eastern parts of the United States and Europe are lowest during the Northern Hemisphere winter months, and highest during the Northern Hemisphere summer months. Figure 4 shows the contrast between the estimated concentrations of $\mathrm{NO}$ and $\mathrm{HO}_{2}$ radical during DJF and JJA, the cycles of which both contribute to more of the aromatics in these areas reacting via the high-yield pathway during the summer. The combined effects on the fate of toluene are shown in panels (e) and (f), which are the log of the branching ratio,

$\log _{10}\left(\frac{\text { Number of toluene peroxy radicals that proceed via reaction with } \mathrm{NO}}{\text { Number of toluene peroxy radicals that proceed via reaction with } \mathrm{HO}_{2}}\right)$.

For example, yellow colors indicate areas where the NO pathway is estimated to dominate by two or more orders of magnitude while blue colors indicate areas where an order of magnitude more toluene molecules are calculated to proceeded via the $\mathrm{HO}_{2}$ pathway. Values where the total toluene 

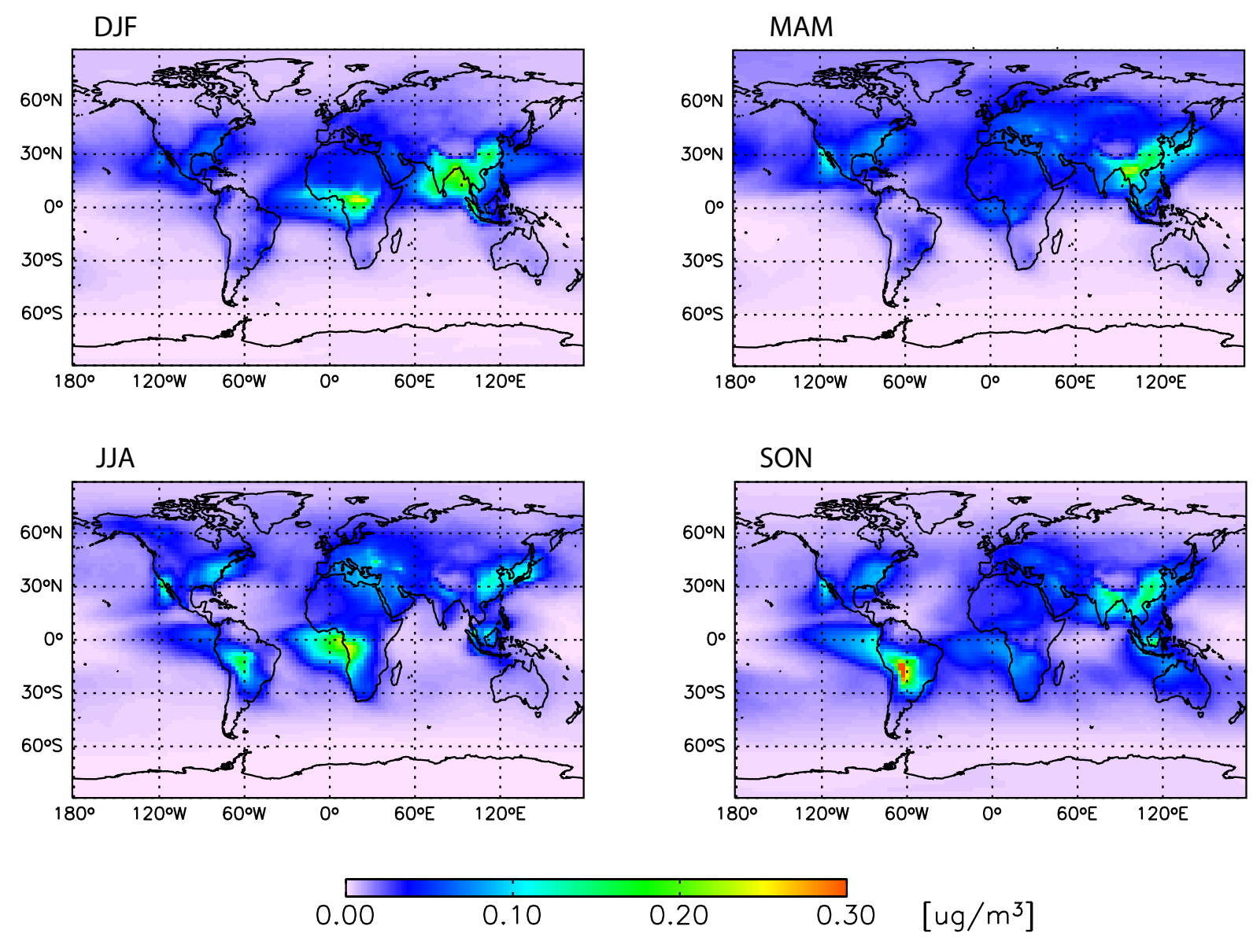

Fig. 3. Seasonal distributions of the total surface-level SOA concentrations from benzene, toluene and xylene.

peroxy radical concentrations are less than $1 \%$ of the maximum global surface concentration are not shown. The $\mathrm{HO}_{2}$ pathway entirely dominates only rarely; however, it is clear that SOA formation via this low- $\mathrm{NO}_{\mathrm{x}}$ pathway is much more important in the eastern United States and Europe during JJA than DJF. Also note that during JJA, SOA production in these areas is not inhibited by increased summertime temperatures as formation of SOA via the low- $\mathrm{NO}_{\mathrm{x}}$ pathway is treated as irreversible. Biogenic sources of organic aerosol are also elevated during the summer. This additional substrate increases SOA production from aromatics via the (3) pathway, but this enhancement is found to be less than $5 \%$. This demonstrates the potential of $\mathrm{NO}_{\mathrm{x}}$ variations, whether perturbed by changes in anthropogenic emissions or modulated by natural seasonal cycles, to influence global SOA yields.

Total aromatic emissions and resulting SOA production rates and burdens are given in Table 5. The burden of SOA from aromatic compounds is estimated here to be $0.08 \mathrm{Tg}$ from a production of $3.5 \mathrm{Tg} / \mathrm{yr}$. Similarly, recent work by Tsigaridis and Kanakidou (2007) estimated SOA burdens from aromatics at $0.04 \mathrm{Tg}$, considering only toluene and $\mathrm{xy}$ - lene. Using the same yields and mechanism reported here, Heald et al. (2007) explored the response of SOA estimates to future climate, land-use and emissions changes in a general circulation model and estimated present day production of SOA from anthropogenic sources to be $1.4 \mathrm{Tg}$ C/yr. Each of these studies highlights the importance of accounting for the $\mathrm{NO}_{\mathrm{x}}$ dependent yields of these species. Overall, the range of estimated global burdens of aromatic SOA from recent simulations $(0.04-0.08 \mathrm{Tg})$ is nearly three times the range of earlier estimates of 0.01-0.03 Tg (Tsigaridis and Kanakidou, 2003).

\section{Sources of uncertainty}

There are several sources of uncertainty in the estimates of SOA from aromatic VOCs. The model for SOA formation outlined in the previous sections includes many parameters whose values are poorly constrained or whose robustness is indeterminate. To begin with, there are reasons why the yield parameters determined from the chamber studies of $\mathrm{Ng}$ et al. (2007) may not be wholly representative of SOA yields from aromatics in the atmosphere. It is not clear the extent to 
(a) NO (DJF)
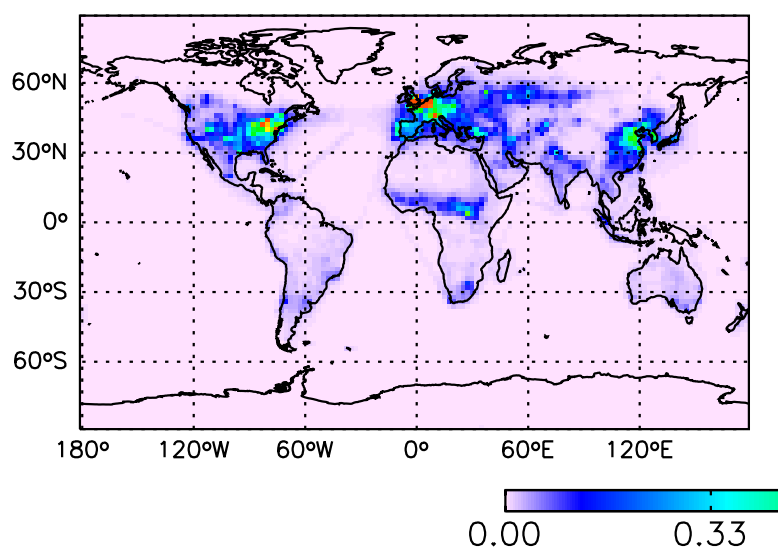

(c) $\mathrm{HO}_{2}$ (DJF)
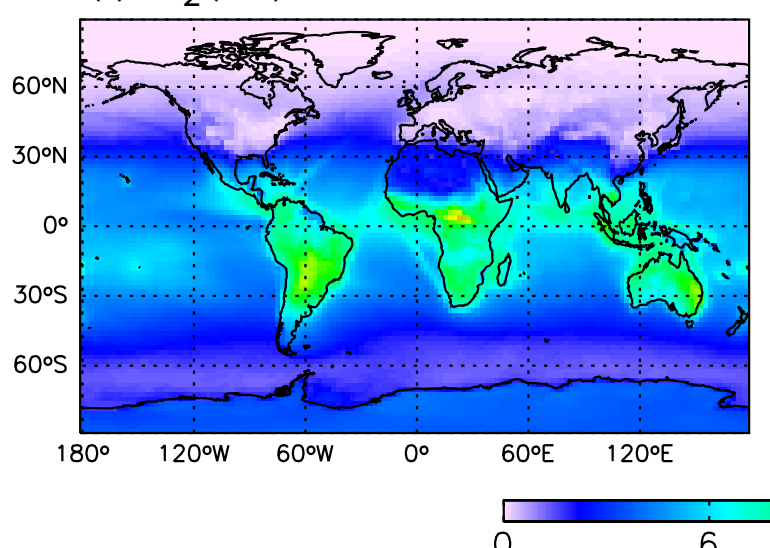

(e) $\log _{10}\left(r_{\mathrm{NO}} / r_{\mathrm{HO}_{2}}\right)$ for toluene (DJF)

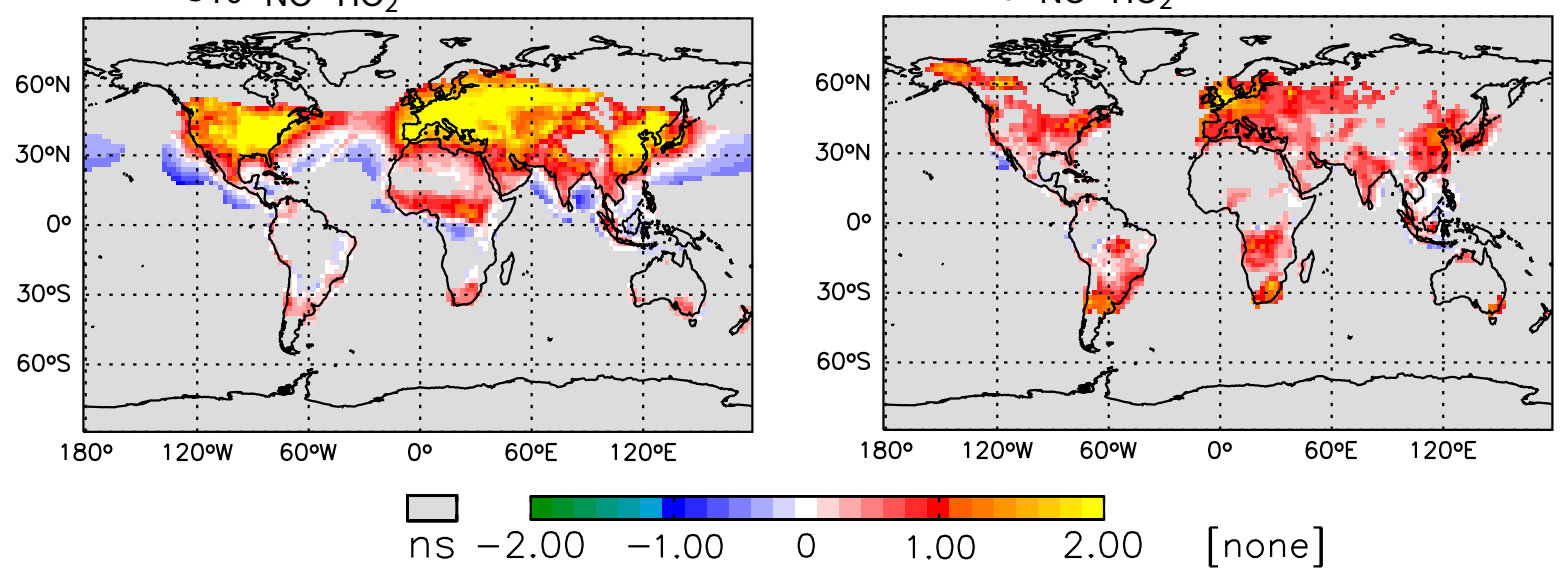

Fig. 4. Panels (a)-(d) are the seasonally averaged surface-level concentrations of $\mathrm{NO}$ and $\mathrm{HO}_{2}$. Panels (e) and (f) show the log of the resulting branching ratio between reaction of the toluene peroxy radical with $\mathrm{NO}$ vs reaction with $\mathrm{HO}_{2}$. Not shown are values where net reacted peroxy radical is $<1 \%$ of the surface-level maximum. Comparing results in the Eastern United States and Europe, both decreased $\mathrm{NO}$ and increased $\mathrm{HO}_{2}$ during JJA lead to increased reaction via the low- $\mathrm{NO}_{\mathrm{x}}$ (high-yield) pathway. 
which yields determined in chamber studies in the presence of high organic aerosol loadings $\left(\sim 10-30 \mu \mathrm{g} \mathrm{m}^{-3}\right)$ can be extrapolated to the atmosphere (Presto and Donahue, 2006; Pathak et al., 2007), particularly given the assumption of irreversible SOA formation at low $\mathrm{NO}_{\mathrm{x}}$ levels. Further, the lack of preexisting organic aerosol (an inorganic seed was used) in these experiments leads to an induction period during which no SOA is formed yet the pool of condensible semivolatile gas-phase species may be depleted. If this depletion is the result of an atmospherically relevant process (as opposed to an experimental artifact, like wall loss), then the resulting SOA yields are likely substantially underestimated by as much as a factor of two at low organic aerosol mass loadings (Kroll et al., 2007). The same reasoning may in part explain why the SOA yields from benzene reported by Martin-Reviejo and Wirtz (2005) are much lower than those determined by $\mathrm{Ng}$ et al. (2007). However, the study of Martin-Reviejo and Wirtz (2005) found constant (i.e. irreversible SOA formation) overall yields in the range of 6$14 \%$ at both high- and low- $\mathrm{NO}_{\mathrm{x}}$ levels. These may perhaps be taken as a lower limit on SOA production from benzene. An upper limit, obtained by doubling the yields of $\mathrm{Ng}$ et al. (2007), could be $40 \%^{2}$ and $70 \%$ at high- and low-NO $\mathrm{NO}_{\mathrm{x}}$ levels, respectively, if indeed the observed SOA formation at low aerosol mass loadings was hindered by lack of an organic substrate during the initial phases of chamber experiments (Kroll et al., 2007). Ignoring nonlinear effects of partitioning, this range of uncertainty translates to global productions of $0.5-3.3 \mathrm{Tg} / \mathrm{yr}$ from benzene alone. Though chamber yields from toluene and $m$-xylene are arguably better characterized (Song et al., 2005; Ng et al., 2007; Song et al., 2007), applying similar ranges of uncertainty to the other aromatics gives a range of $1.0-6.8 \mathrm{Tg} / \mathrm{yr}$

However, the global SOA production depends upon the available substrate into which semivolatile species partition, the specification of which is another large source of uncertainty. The ratio of total organic aerosol mass to that of the organic carbon aerosol mass is assumed to be 2.1 in the present work. Changing this value from the previously assumed value of 1.4 leads to a $20 \%$ increase in total SOA production. The study of Tsigaridis and Kanakidou (2003) estimated that including ammonium sulfate aerosol in the specification of the available substrate for partitioning nearly dou-

\footnotetext{
${ }^{2}$ This number comes from doubling the "global" yield of SOA from benzene via the high- $\mathrm{NO}_{\mathrm{x}}$ pathway of $20 \%$, calculated as the total mass of benzene that reacts via this pathway divided by the total mass of SOA formed via this pathway throughout the model over the course of the year-long simulation. Similarly, the global yields from toluene and xylene from the high- $\mathrm{NO}_{\mathrm{x}}$ pathway were found to be $6 \%$ and $3 \%$, respectively, corresponding to chamber yields extrapolated to organic aerosol mass loadings of $5 \mu \mathrm{g} \mathrm{m}^{-3}$ in $\mathrm{Ng}$ et al. (2007). That global yields align with the chamber yields in a consistent manner suggests that extrapolating variations in chamber yields directly to global SOA production estimates is a reasonable first-order approximation.
}

bled global SOA production. The overall effect of the substrate could therefore seemingly change the estimated SOA concentrations by as much as $-20 \%$ to $+100 \%$, resulting in a range of SOA production of 2.8 to $7.0 \mathrm{Tg} / \mathrm{yr}$. In contrast to models that assume any organic aerosol mass as part of the available substrate, Song et al. (2007) found that the presence of a hydrophobic organic seed did not enhance partitioning. The implications would be an overestimate of SOA formation in the current model near sources of primary (hydrophobic) organic aerosol. Other factors that affect the partitioning of all types of SOA include RH (Cocker et al., 2001; Pun and Seigneur, 2007), and temperature. The dependence of partitioning on temperature is approximated using an effective enthalpy of vaporization, $\triangle H_{v}$. Given the large range of measured values of $\Delta H_{v}$ for SOA $\left(11-43 \mathrm{~kJ} \mathrm{~mol}^{-1}\right)$ and typical components found in SOA ( $>50 \mathrm{~kJ} \mathrm{~mol}^{-1}$ for many) in the work of Offenberg et al. (2006), coupled with the large sensitivity of global SOA models to this parameter (for example, in Henze and Seinfeld (2006) a $19 \%$ increase in $\triangle H_{v}$ was found to result in a $28 \%$ and $50 \%$ increase in the SOA production and burden, respectively), the temperature dependence of SOA yields clearly imparts a large degree of uncertainty to such calculations (Tsigaridis and Kanakidou, 2003), particularly the SOA burden in the troposphere (Henze and Seinfeld, 2006).

Regardless of the treatment of partitioning, it is not certain that the gas-phase chemical reaction scheme inferred from the chamber studies, (R1)-(R3), will similarly dominate in the atmosphere. As noted in Sect. 2, this scheme does not include reaction of the bicyclic peroxy radicals with themselves or other peroxy radicals. The consequences of reaction with other peroxy radicals would likely be formation of species with different volatility than those formed from reaction with $\mathrm{HO}_{2}$. Observational constraints of the atmospheric concentrations of $\mathrm{RO}_{2}$ and $\mathrm{HO}_{2}$ have found $\mathrm{RO}_{2}$ to $\mathrm{HO}_{2}$ ratios ranging from 1:1 (Hanke et al., 2002) to up to 5:1 (Mihelcic et al., 2003; Stevens et al., 1997), though since these were determined at ground level, they likely represent upper bounds on this ratio in the atmosphere. However, $57 \%$ of the SOA production in the present model occurs above the boundary layer, so SOA production could be likely affected by at most $43 \%$ if such competition takes place only near VOC sources. For this to happen, the peroxy radical concentrations must exceed those of $\mathrm{NO}$ and $\mathrm{HO}_{2}$ by much more than an order of magnitude as the rate constant for $\mathrm{RO}_{2}+$ $\mathrm{R}^{\prime} \mathrm{O}_{2}$ at $298 \mathrm{~K}$ is slower (likely $<1 \times 10^{-14} \mathrm{~cm}^{3}$ molecule ${ }^{-1}$ $\mathrm{s}^{-1}$ given their level of substitution) than $k_{N}\left(8.5 \times 10^{-12}\right.$ $\mathrm{cm}^{3}$ molecule $\left.{ }^{-1} \mathrm{~s}^{-1}\right)$ or $k_{H}\left(1.5 \times 10^{-11} \mathrm{~cm}^{3}\right.$ molecule ${ }^{-1}$ $\mathrm{s}^{-1}$ ). Hence this seems unlikely, as even the observed ratios of $\mathrm{RO}_{2}$ to $\mathrm{HO}_{2}$ are not that high. Self-reaction of the bicyclic peroxy radical also seems rare since estimated concentrations of even the parent aromatic species are typically on the order of only a few ppb near source regions, where modeled $\mathrm{NO}_{\mathrm{x}}$ concentrations are of order $0.1 \mathrm{ppb}$ and/or $\mathrm{HO}_{2}$ are $10 \mathrm{ppt}$. 
Table 5. Global SOA budgets.

\begin{tabular}{lccc}
\hline Hydrocarbon & Emission (Tg/yr) & SOA Production (Tg/yr) & Burden $(\mathrm{Tg})$ \\
\hline terpenes & 121 & 8.7 & 0.22 \\
alcohols & 38.3 & 1.6 & 0.03 \\
sesquiterpenes & 14.8 & 2.1 & 0.03 \\
isoprene & 461 & 14.4 & 0.45 \\
aromatics & 18.8 & 3.5 & 0.08 \\
total & 654 & 30.3 & 0.81 \\
\hline
\end{tabular}

Finally, in addition to the mechanism for SOA formation from aromatics considered here, there have been several other works that present means by which the SOA yields from aromatics may be much higher than originally estimated by Odum et al. $(1996,1997)$. Aqueous-phase chemical production of nonvolatile species in cloud droplets (Ervens et al., 2004) has been shown to be an important mechanism for SOA production from isoprene (Lim et al., 2005), and could potentially be an important pathway for aromatics (Sorooshian et al., 2007). Prolonged photochemical aging towards less volatile species (Donahue et al., 2006), heterogeneous chemistry (Na et al., 2006) and even subsequent evaporation of organic aerosol (Kwan et al., 2006) are effects of (as of yet) undetermined magnitude for aromatics. Irreversible uptake of methylglyoxal and glyoxal (Liggio et al., 2005) may also be a substantial source of SOA (Fu et al., 2008; Volkamer et al., 2007).

Lastly, uncertainty in the emissions inventories, of not only aromatics but $\mathrm{NO}_{\mathrm{x}}$, biogenics, and primary organic aerosols, can be important, as are aspects of the model such as transport, deposition and land cover. For example, implementation of the same mechanism for SOA formation by Heald et al. (2007) resulted in SOA production of $1.4 \mathrm{Tg} \mathrm{C} / \mathrm{yr}$ from aromatics and $22.9 \mathrm{Tg} \mathrm{C} / \mathrm{yr}$ from monoterpenes and isoprene for the year 2000. While this is similar in magnitude to the amount of SOA produced from aromatics in the present work (assuming an OA/OC ratio of 2.1), the percentage of global SOA production from aromatics in Heald et al. (2007) $(6 \%)$ is a factors of two less than the amount reported here $(12 \%)$.

Overall, there are many sources of uncertainty in the present model estimates of SOA production from aromatic VOCs. As the uncertainty range from each source (not even considering their likelihood), is highly speculative, a quantitative estimate of the combined total uncertainty is difficult. Nevertheless, we postulate a conservative range of 2$12 \mathrm{Tg} / \mathrm{yr}$ owing to the combination of the sources of uncertainty discussed above, even if only in a highly approximate fashion. Clearly the maximum theoretical limit is closer to $25-30 \mathrm{Tg} / \mathrm{yr}$, though this value should not be taken as an upper limit on model estimates unless a mechanism for producing this much SOA from aromatic VOCs can be specified well enough for implementation in global models.

\section{Anthropogenic vs biogenic SOA}

Table 5 also presents the emissions and resulting production rates and burdens of SOA from biogenic species, where for simplicity we consider all aromatic sources to be anthropogenic, though undoubtedly some of the biomass burning sources are naturally occurring. Even though aromatic SOA is appreciable, the global SOA burden is dominated by biogenic sources, about $50 \%$ of which is attributable to isoprene, as predicted based on current SOA yields from laboratory chamber studies. As such, addition of aromatic SOA does not significantly affect global estimates of biogenic SOA through nonlinear effects, though it may have a stronger influence in future emissions scenarios (Heald et al., 2007; Tsigaridis and Kanakidou, 2007).

While the bulk of the total modeled SOA is biogenic in origin, there are regions of the global distribution where concentrations of SOA from aromatics are predicted to be equal or larger than those from biogenics. Figure 5 shows the log of the ratio of aromatic to biogenic SOA concentrations,

$\log _{10}\left(\frac{\left[\mathrm{SOA}_{\text {arom }}\right]}{\left[\mathrm{SOA}_{\text {biogenic }}\right]}\right)$

excluding locations where the total SOA concentration is less than $0.05 \mu \mathrm{g} / \mathrm{m}^{3}$. During DJF and MAM, much of the outflow regions in the Northern Hemisphere are dominated by anthropogenic SOA. Nevertheless, SOA concentrations in these areas are still small, $<0.1 \mu \mathrm{g} / \mathrm{m}^{3}$, as can be seen by comparison to Fig. 3. Further, concentrations in these regions are typically much smaller than the total (primary plus secondary) organic aerosol. For example, Fig. 6 shows the profile of SOA concentrations at $70^{\circ} \mathrm{W}$, an area identified in Fig. 5 where the SOA is predominantly anthropogenic in origin. While SOA concentrations from aromatics, see panel (a), are greater than from other sources, panel (b), the total SOA concentrations are small, particularly in comparison to total carbon aerosol concentrations, panels (c)-(d).

As such, the revised estimates of total carbonaceous aerosol from this work alone do not likely explain the "missing source" of SOA noted in previous model estimates of OC aerosol in ACE-Asia (Heald et al., 2005), nor the magnitude and variability of soluble $\mathrm{OC}$ from observations during the ICARTT campaign of summer, 2004 (Heald et al., 

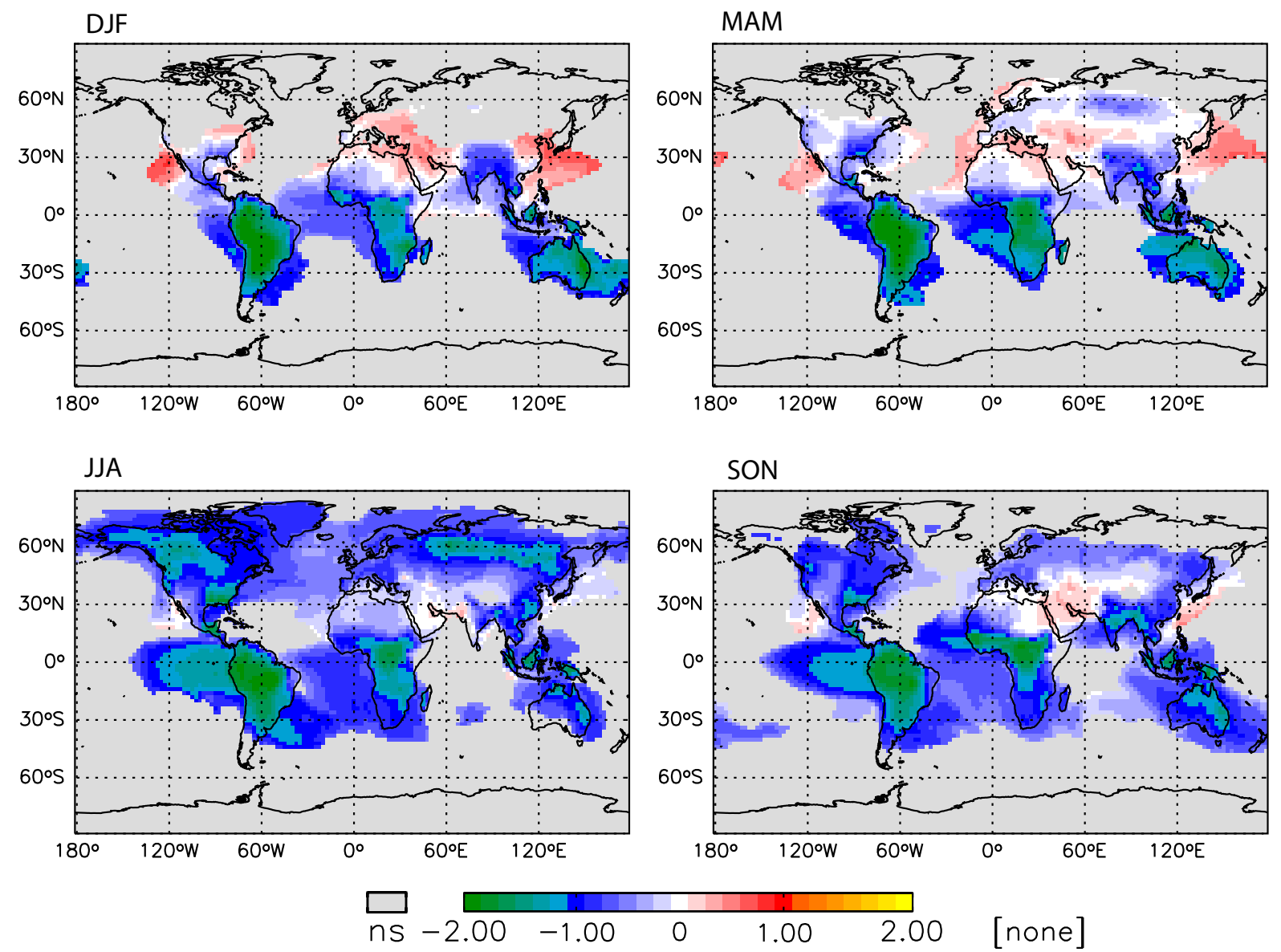

Fig. 5. The $\log$ of the ratio of seasonally averaged surface concentrations of anthropogenic to biogenic $\mathrm{SOA}, \log _{10}\left(\frac{\left[\mathrm{SOA}_{\text {arom }}\right]}{\left[\mathrm{SOA}_{\mathrm{biogenic}}\right]}\right)$, omitting values where the total SOA concentration is less than $0.05 \mu \mathrm{g} / \mathrm{m}^{3}$. For simplicity, biomass burning sources of aromatics are considered to be anthropogenic.

2006). In Europe, the importance of anthropogenic SOA in winter and biogenic SOA in the summer is in general agreement with recent findings (Simpson et al., 2007; Gelencsér et al., 2007), though more detailed comparison is called for. Over the Northeastern United States during JJA, the estimated SOA from aromatics via the pathways considered here is still smaller than the anthropogenic source of SOA suggested by de Gouw et al. (2008), though use of the revised yields of $\mathrm{Ng}$ et al. (2007) did improve the agreement over de Gouw et al. (2005). While it is tempting to directly compare the results of the present calculation to the observations of SOA formation in Mexico City reported by Volkamer et al. (2006), the results of this global modeling study are too coarse to resolve specific urban scale pollution events. Even when considering the sources of uncertainty discussed in Section 5, it is evident that additional mechanisms for anthropogenic SOA formation still exist beyond those presently considered. Further consideration of the role of intermediate volatility compounds (Robinson et al., 2007) and additional SOA precursors appear vital to our understanding of global SOA (Goldstein and Galbally, 2007).

\section{Conclusions}

The global chemical transport model GEOS-Chem is updated to include simulation of SOA formation from the aromatic species benzene, toluene and xylene. Following the suggestion of Presto and Donahue (2006), a simple mechanism is presented that accounts for the competition between low and high- $\mathrm{NO}_{\mathrm{x}}$ pathways on SOA formation in a continuous fashion. Depending upon the immediate chemical environment, secondary peroxy radicals from photooxidation of aromatics by $\mathrm{OH}$ react with either $\mathrm{NO}$ or $\mathrm{HO}_{2}$ radical. Formation of SOA from reaction with NO leads to reversible formation of SOA following the two-product model of Odum et al. $(1996,1997)$ using empirically determined yield and partitioning coefficients from the high- $\mathrm{NO}_{\mathrm{x}}$ studies of $\mathrm{Ng}$ et al. (2007). Aromatic peroxy radicals that react with $\mathrm{HO}_{2}$ radical are treated as forming SOA irreversibly, following the low- $\mathrm{NO}_{\mathrm{x}}$ results of $\mathrm{Ng}$ et al. (2007). This approach to treating $\mathrm{NO}_{\mathrm{x}}$ dependence is general and could (with enough empirical data) be extended to address the $\mathrm{NO}_{\mathrm{x}}$ dependence of other species that are associated enough with sources of 
(a) SOA from aromatic species

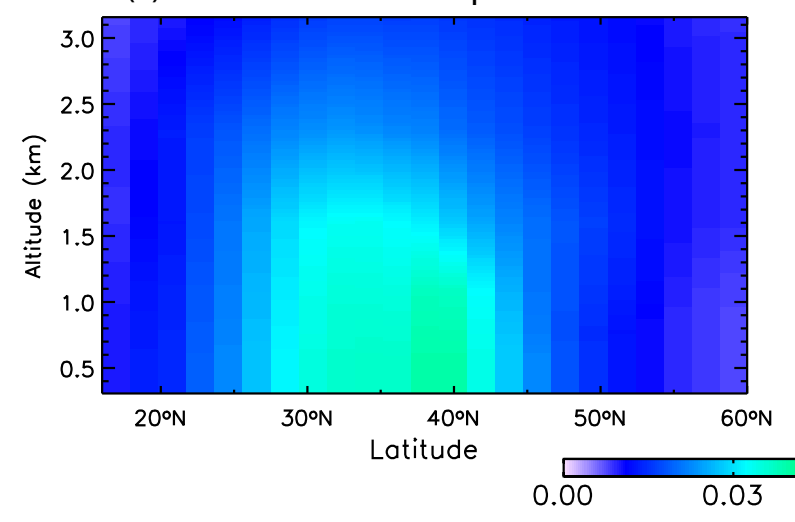

(c) SOA from all species

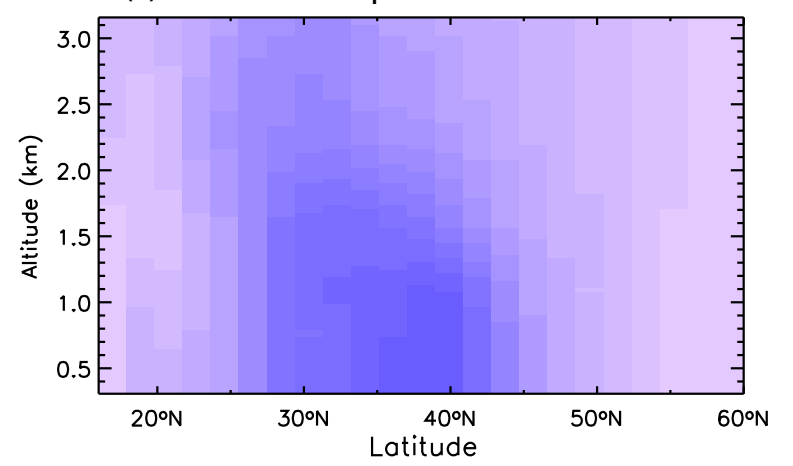

(b) SOA from non-aromatic species

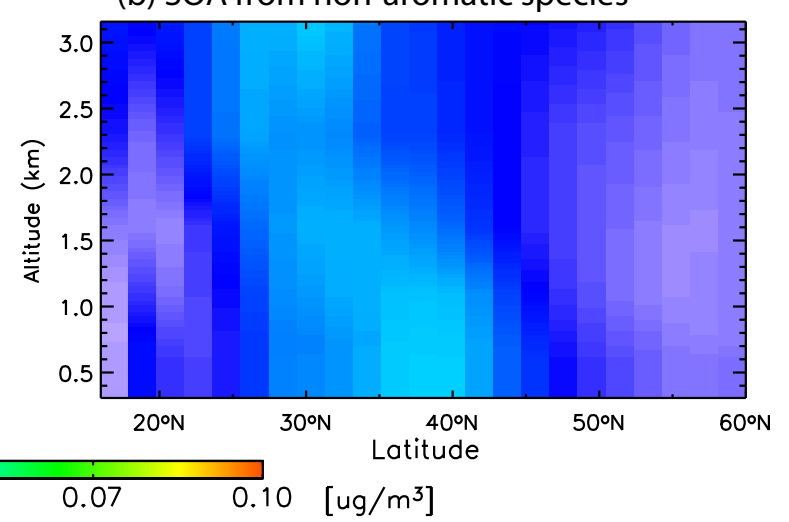

(d) OC (primary and secondary)
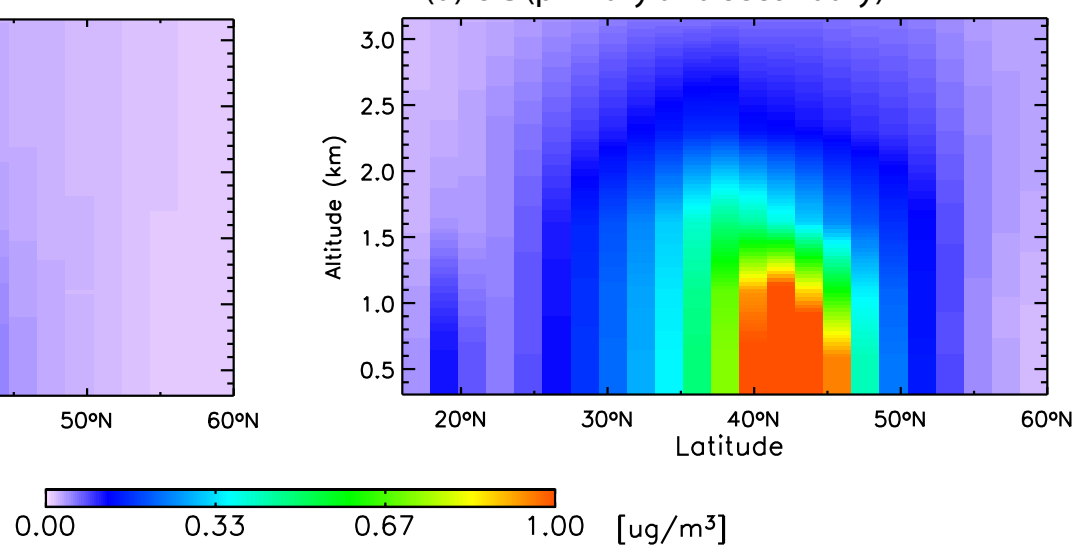

Fig. 6. A profile of SOA concentrations at $70^{\circ} \mathrm{W}$ (east of the United States) during DJF. Panels (a) and (b) show the linear contributions from anthropogenic and biogenic sources, respectively. Noting the change in scale, panels (c) and (d) show the total SOA from all sources and the total organic carbon aerosol from primary and secondary sources.

$\mathrm{NO}_{\mathrm{x}}$ to warrant discrimination between the two pathways. For the aromatic species, explicitly considering both pathways was found to be important as substantial amounts (25\% or higher) of each aromatic species proceed via each pathway. In contrast, implementing a similar model description for monoterpenes, sesquiterpenes, or isoprene, largely emitted in low- $\mathrm{NO}_{\mathrm{x}}$ environments, may not be as crucial for estimating their contributions to SOA in global models.

Previously assumed to generate negligible amounts of SOA because of its low reactivity with $\mathrm{OH}$, benzene is estimated in this work to be the most important aromatic species with regards to global formation of SOA owing to its low initial reactivity and the location of its emissions. Its low initial reactivity allows benzene to be transported away from source regions, where $[\mathrm{NO}] /\left[\mathrm{HO}_{2}\right]$ ratios are high, to more remote regions, where this ratio is lower and, hence, the ultimate yield of SOA is higher. In total, nearly $75 \%$ of the aromatic SOA is formed via the low- $\mathrm{NO}_{\mathrm{x}}$ pathway, though only $39 \%$ percent of the aromatic species react via this mechanism. Predicted SOA concentrations from aromatics in the Eastern United States and Europe are actually largest during the summer, owing to both higher $\mathrm{HO}_{2}$ radical concentrations and lower $\mathrm{NO}$ concentrations. Influence of $\mathrm{NO}_{\mathrm{x}}$ variability on SOA formation is particularly interesting as current models may underestimate seasonal $\mathrm{NO}_{\mathrm{x}}$ cycles in many areas as indicated by observations from GOME (van Noije et al., 2006; Wang et al., 2007), though further analysis is warranted.

Even though the predicted burden and production rate of aromatic SOA is considerably more than previous estimates (Tsigaridis and Kanakidou, 2003, 2007), the contribution of these sources to global SOA is small relative to contributions from monoterpenes and isoprene, which alone are estimated to comprise $82 \%$ of the global SOA burden. However, owing to differences in spatial distributions of sources and seasons of peak production, there are regions in which aromatic SOA is predicted to contribute substantially to, and even dominate, the local SOA concentrations, such as outflow regions from North America and South East Asia during the wintertime. The contribution of aromatic SOA to carbonaceous aerosol may also affect interpretation of total organic carbon aerosol concentrations from surface stations in which winter concentrations have been assumed to be primary in origin (Liao et al., 2007). 
Comprehensive model treatment of SOA is difficult owing to a large range of effects not yet included, from interactions of aqueous and organic phases (Pun and Seigneur, 2007) to effects of particle acidity on yields from isoprene (Surratt et al., 2007). Recent works by Presto and Donahue (2006) and Pathak et al. (2007) also emphasize additional factors that complicate the interpretation of parameterized SOA yields from chamber data, such as low aerosol mass loading; the presence and content of the aerosol seed particles in such studies can have important outcomes on the derived yields (Kroll et al., 2007; Song et al., 2007; Chan et al., 2007). Further, the mechanisms governing the $\mathrm{NO}_{\mathrm{x}}$ dependence of SOA formation from aromatics as modeled here may differ in the actual atmosphere. Uncertainties in biogenic emissions estimates are frequently cited; uncertainties of even the aromatic emissions are possibly as large as a factor of two or more (Warneke et al., 2007). The combination of all such uncertainties in the mechanism presented here could produce a range of predictions. Though quantifying the effects of as-of-yet uncharacterized processes is highly subjective, it seems reasonable to speculate that this pathway of SOA production from aromatics via partitioning of secondary gas-phase semivolatile species could result in a range of $2-12 \mathrm{Tg} / \mathrm{yr}$.

Compared to observations from urban (influenced) air masses (de Gouw et al., 2005; Volkamer et al., 2006; Kleinman et al., 2007; Weber et al., 2007; de Gouw et al., 2008), it would appear that the anthropogenic component of SOA is still being underestimated, despite the fact that the estimates given here produce two to three times more anthropogenic SOA than previous works. Consideration of additional mechanisms for formation of SOA beyond those considered here, such as evolution of the constituents' volatility (Donahue et al., 2006), the oxidation of intermediate-volatility compounds (Robinson et al., 2007), or the potential for additional species such as glyoxal and methylglyoxal to make SOA (Fu et al., 2008; Liggio et al., 2005; Volkamer et al., 2007) would appear vital to our description of anthropogenic SOA. Further efforts towards understanding such processes and sources of SOA are important for assessing both the anthropogenic and biogenic contribution to widespread observations of oxygenated organic aerosol (Zhang et al., 2007) and the overall budget of organic carbon species in the atmosphere (Goldstein and Galbally, 2007).

Overall, the importance of $\mathrm{NO}_{\mathrm{x}}$ on estimating yields of SOA from aromatics is clear. This work highlights the importance of additional studies of the $\mathrm{NO}_{\mathrm{x}}$ dependence of SOA formation from other species, and the role that such dependance plays on SOA yields of long lived hydrocarbons in general, as this represents an important mechanism by which anthropogenic activity can affect global SOA. This is of concern for not only interpretation of current measurements of organic aerosol, but also for estimates of the effects of future climate and emissions changes on global aerosol burdens (Heald et al., 2007; Tsigaridis and Kanakidou, 2007).
Acknowledgements. This work was supported by U.S. Environmental Protection Agency, grant R832158, and the National Science Foundation, grant NSF ITR AP\&IM 0205198, which provided access to the TeraGrid resources at the National Center for Supercomputing Applications.

Edited by: R. Volkamer

\section{References}

Andreae, M. O. and Merlet, P.: Emission of trace gases and aerosols from biomass burning, Global Biogeochem. Cy., 15, 955-966, 2001.

Atkinson, R., Baulch, D. L., Cox, R. A., Hampson, R. F., Kerr, J. A., Rossi, M. J., and Troe, J.: Evaluated kinetic and photochemical data for atmospheric chemistry: Supplement VI - IUPAC subcommittee on gas kinetic data evaluation for atmospheric chemistry, J. Phys. Chem. Ref. Data, 26, 1329-1499, 1997.

Benkovitz, C. M., Scholtz, M. T., Pacyna, J., Tarrason, L., Dignon, J., Voldner, E. C., Spiro, P. A., Logan, J. A., and Graedel, T. E.: Global gridded inventories of anthropogenic emissions of sulfur and nitrogen, J. Geophys. Res., 101, 29239-29 253, 1996.

Bey, I., Jacob, D. J., Yantosca, R. M., Logan, J. A., Field, B. D., Fiore, A. M., Li, Q. B., Liu, H. G. Y., Mickley, L. J., and Schultz, M. G.: Global modeling of tropospheric chemistry with assimilated meteorology: Model description and evaluation, J. Geophys. Res., 106, 23 073-23 095, 2001.

Calvert, J., Atkinson, R., Becker, K. H., Kamens, R. M., Seinfeld, J. H., Wallington, T. J., and Yarwood, G.: The mechanisms of atmospheric oxidation of aromatic hyrdocarbons, Oxford University Press, New York, 2002.

Chan, A. W. H., Kroll, J. H., Ng, N. L., and Seinfeld, J. H.: Kinetic modeling of secondary organic aerosol formation: effects of particle- and gas-phase reactions of semivolatile products, Atmos. Chem. Phys., 7, 4135-4147, 2007, http://www.atmos-chem-phys.net/7/4135/2007/.

Chung, S. H. and Seinfeld, J. H.: Global distribution and climate forcing of carbonaceous aerosols, J. Geophys. Res., 107, 4407, doi:10.1029/2001JD001397, 2002.

Cocker, D. R., David, R., Mader, B. T., Kalberer, M., Richard, C., and Seinfeld, J. H.: The effect of water on gas-particle partitioning of secondary organic aerosol, II, $m$-xylene and 1, 3, 5trimethylbenzene photooxidation systems, Atmos. Environ., 35, 6073-6085, 2001.

de Gouw, J. A., Middlebrook, A. M., Warneke, C., Goldan, P. D., Kuster, W. C., Roberts, J. M., Fehsenfeld, F. C., Worsnop, D. R., Canagaratna, M. R., Pszenny, A. A. P., Keene, W. C., Marchewka, M., Bertman, S. B., and Bates, T. S.: Budget of organic carbon in a polluted atmosphere: Results from the New England Air Quality Study in 2002, J. Geophys. Res., 110, D16305, doi:10.1029/2004JD005623, 2005.

de Gouw, J. A., Brock, C. A., Atlas, E. L., Bates, T. S., Fehsenfeld, F. C., Goldan, P. D., Holloway, J. S., Kuster, W. C., Lerner, B. M., Mattew, B. M., Middlebrook, A. M., Onasch, T. B., Peltier, R. E., Quinn, P. K., Senff, C. J., Stohl, A., Sullivan, A. P., Trainer, M., Warneke, C., Weber, R. J., and Williams, E. J.: Sources of particulate matter in the Northeastern United States: 1. Direct emissions and secondary formation of organic matter in urban plumes, J. Geophys. Res., 113, D08301, doi:10.1029/2007JD009243, 2008. 
Donahue, N. M., Robinson, A. L., Stanier, C. O., and Pandis, S. N.: The coupled dilution, partitioning, and chemical aging of semivolatile organics, Environ. Sci. Technol., 40, 2635-2643, 2006.

Eberhard, J. and Howard, C. J.: Rate coefficients for the reactions of some C-3 to C-5 hydrocarbon peroxy radicals with NO, J. Phys. Chem. A, 101, 3360-3366, 1997.

Ervens, B., Feingold, G., Frost, G. J., and Kreidenweis: A modeling study of aqueous production of dicarboxylic acids: 1. Chemical pathways and speciated organic mass production, J. Geophys. Res., 109, D15206, doi:10.1029/2004JD004575, 2004.

Fan, J. W. and Zhang, R. Y.: Atmospheric oxidation mechanism of p-xylene: A density functional theory study, J. Phys. Chem. A, 110, 7728-7737, 2006.

Fu, T.-M., Jacob, D. J., Wittrock, F., Burrows, J. P., Vrekoussis, M., and Henze, D. K.: Global budgets of atmospheric glyoxal and methylglyoxal, and implications for formation of secondary organic aerosols, J. Geophys. Res., in press, 2008.

Gelencsér, A., May, B., Simpson, D., Sanchez-Ochoa, A., Kasper-Giebl, A., Puxbaum, H., Caseiro, A., Pio, C., and Legrand, M.: Source apportionment of PM2.5 organic aerosol over Europe: Primary/secondary, natural/anthropogenic, and fossil/biogenic origin, J. Geophys. Res., 112, D23S04, doi:10.1029/2006JD008094, 2007.

Giglio, L., van der Werf, G. R., Randerson, J. T., Collatz, G. J., and Kasibhatla, P.: Global estimation of burned area using MODIS active fire observations, Atmos. Chem. Phys., 6, 957-974, 2006, http://www.atmos-chem-phys.net/6/957/2006/.

Goldstein, A. H. and Galbally, I. E.: Known and unexplored organic constituents in the earth's atmosphere, Environ. Sci. Technol., 41, 1514-1521, 2007.

Guenther, A., Karl, T., Harley, P., Wiedinmyer, C., Palmer, P. I., and Geron, C.: Estimates of global terrestrial isoprene emissions using MEGAN (Model of Emissions of Gases and Aerosols from Nature), Atmos. Chem. Phys., 6, 107-173, 2006,

http://www.atmos-chem-phys.net/6/107/2006/.

Hanke, M., Uecker, J., Reiner, T., Arnold, F.:Atmospheric peroxy radicals: ROXMAS, a new mass- spectrometric methodology for speciated measurements of $\mathrm{HO}_{2}$ and $\sum \mathrm{RO}_{2}$ and first results, Int. J. Mass Spectrom., 213, 91-99, 2002.

Heald, C. L., Jacob, D. J., Park, R. J., Russell, L. M., Huebert, B. J., Seinfeld, J. H., Liao, H., and Weber, R. J.: A large organic aerosol source in the free troposphere missing from current models, Geophys. Res. Lett., 32, L18809, doi:10.1029/2005GL023831, 2005.

Heald, C. L., Jacob, D. J., Turquety, S., Hudman, R. C., Weber, R. J., Sullivan, A. P., Peltier, R. E., Atlas, E. L., de Gouw, J. A., Warneke, C., Holloway, J. S., Neuman, J. A., Flocke, F. M., and Seinfeld, J. H.: Concentrations and sources of organic carbon aerosols in the free troposphere over North America, J. Geophys. Res., 111, 2006.

Heald, C. L., Henze, D. K., Horowitz, L. W., Feddema, J., Lamarque, J. F., Guenther, A., Hess, P., Vitt, F., Seinfeld, J. H., Goldstein, A. H., and Fung, I.: Predicted change in global secondary organic aerosol concentrations in response to future climate, emissions, and land-use change, J. Geophys. Res., 113, D05211, doi:10.1029/2007JD009092, 2008.

Henze, D. K. and Seinfeld, J. H.: Global secondary organic aerosol from isoprene oxidation, Geophys. Res. Lett., 33, L09812,
doi:10.1029/2006GL025976, 2006.

Hudman, R. C., Jacob, D. J., Turquety, S., Leibensperger, E. M., Murray, L. T., Wu, S., Gilliland, A. B., Avery, M., Bertram, T. H., Brune, W., Cohen, R. C., Dibb, J. E., Flocke, F. M., Fried, A., Holloway, J., Neuman, J. A., Orville, R., Perring, A., Ren, X., Sachse, G. W., Singh, H. B., Swanson, A., and Wooldridge, P. J.: Surface and lightning sources of nitrogen oxides over the United States: magnitudes, chemical evolution, and outflow, J. Geophys. Res., 112, D12S05, doi:10.1029/2006JD007912, 2007.

Hurley, M. D., Sokolov, O., Wallington, T. J., Takekawa, H., Karasawa, M., Klotz, B., Barnes, I., and Becker, K. H.: Organic aerosol formation during the atmospheric degradation of toluene, Environ. Sci. Technol., 35, 1358-1366, 2001.

Johnson, D., Cassanelli, P., and Cox, R. A.: Isomerization of simple alkoxyl radicals: New temperature-dependent rate data and structure activity relationship, J. Phys. Chem. A, 108, 519-523, 2004.

Johnson, D., Jenkin, M. E., Wirtz, K., and Martin-Reviejo, M.: Simulating the formation of secondary organic aerosol from the photooxidation of aromatic hydrocarbons, Environ. Chem., 2, 3548, 2005.

Johnson, D., Utembe, S. R., Jenkin, M. J., Derwent, R. G., Hayman, G. D., Alfarra, M. R., Coe, H., and McFiggans, G.: Simulating regional scale secondary organic aerosol formation during the Torch 2003 campaign in the southern UK, Atmos. Chem. Phys., 6, 403-418, 2006, http://www.atmos-chem-phys.net/6/403/2006/.

Kanakidou, M., Seinfeld, J. H., Pandis, S. N., Barnes, I., Dentener, F. J., Facchini, M. C., Van Dingenen, R., Ervens, B., Nenes, A., Nielsen, C. J., Swietlicki, E., Putaud, J. P., Balkanski, Y., Fuzzi, S., Horth, J., Moortgat, G. K., Winterhalter, R., Myhre, C. E. L., Tsigaridis, K., Vignati, E., Stephanou, E. G., and Wilson, J.: Organic aerosol and global climate modelling: A review, Atmos. Chem. Phys., 5, 1053-1123, 2005,

http://www.atmos-chem-phys.net/5/1053/2005/.

Kleinman, L. I., Springston, S. R., Daum, P. H., Lee, Y. N., Nunnermacker, L. J., Senum, G. I., Wang, J., Weinstein-Lloyd, J., Alexander, M. L., Hubbe, J., Ortega, J., Canagaratna, M. R., and Jayne, J.: The time evolution of aerosol composition over the Mexico City plateau, Atmos.Chem.Phys.Discuss., 7, 1446114509, 2007.

Klotz, B., Volkamer, R., Hurley, M. D., Andersen, M. P. S., Nielsen, O. J., Barnes, I., Ima- mura, T., Wirtz, K., Becker, K. H. Platt, U., Wallington, T. J. and Washida, N.: OH-initiated oxidation of benzene - Part II. Influence of elevated NOx concentrations, Phys. Chem. Chem. Phys., 4, 4399-4411, 2002

Koch, R., Knispel, R., Elend, M., Siese, M., and Zetzsch, C.: Consecutive reactions of aromatic-OH adducts with $\mathrm{NO}$, $\mathrm{NO} 2$ and $\mathrm{O}-2$ : benzene, naphthalene, toluene, $\mathrm{m}-$ and $\mathrm{p}-$ xylene, hexamethylbenzene, phenol, m-cresol and aniline, Atmos. Chem. Phys., 7, 2057-2071, 2007, http://www.atmoschem-phys.net/7/2057/2007/.

Kroll, J. H., Chan, A. W. H., Ng, N. L., Flagan, R. C., and Seinfeld, J. H.: Reactions of semivolatile organics and their effects on secondary organic aerosol formation, Environ. Sci. Technol., 41, 3545-3550, 2007.

Kwan, A. J., Crounse, J. D., Clarke, A. D., Shinozuka, Y., Anderson, B. E., Crawford, J. H., Avery, M. A., McNaughton, C. S., Brune, W. H., Singh, H. B., and Wennberg, P. O.: 
On the flux of oxygenated volatile organic compounds from organic aerosol oxidation, Geophys. Res. Lett., 33, L15815, doi:10.1029/2006GL026144, 2006.

Lack, D. A., Tie, X. X., Bofinger, N. D., Wiegand, A. N., and Madronich, S.: Seasonal variability of secondary organic aerosol: A global modeling study, J. Geophys. Res., 109, D03203, doi:10.1029/2003JD003418, 2004.

Liao, H., Henze, D. K., Seinfeld, J. H., Wu, S., and Mickley, L. J.: Biogenic secondary organic aerosol over the United States: Comparison of climatological simulations with observations, J. Geophys. Res., 112, D06201, doi:10.1029/2006JD007813, 2007.

Liggio, J., Li, S.-M., and McLaren, R.: Reactive uptake of glyoxal by particulate matter, J. Geophys. Res., 110, D10304, doi:10.1029/2004JD005113, 2005.

Lightfoot, P. D., Cox, R. A., Crowley, J. N., Destriau, M., Hayman, G. D., Jenkin, M. E., Moortgat, G. K., and Zabel, F.: Organic peroxy-radicals - kinetics, spectroscopy and tropospheric chemistry, Atmos. Environ., 26, 1805-1961, 1992.

Lim, H. J., Carlton, A. G., and Turpin, B. J.: Isoprene forms secondary organic aerosol through cloud processing: Model simulations, Environ. Sci. Technol., 39, 4441-4446, 2005.

Liu, H. Y., Jacob, D. J., Bey, I., and Yantosca, R. M.: Constraints from $\mathrm{Pb}-210$ and $\mathrm{Be}-7$ on wet deposition and transport in a global three-dimensional chemical tracer model driven by assimilated meteorological fields, J. Geophys. Res., 106, 12 109-12 128, 2001.

Martin, R. V., Chance, K., Jacob, D. J., Kurosu, T. P., Spurr, R. J. D., Bucsela, E., Gleason, J. F., Palmer, P. I., Bey, I., Fiore, A. M., Li, Q. B., Yantosca, R. M., and Koelemeijer, R. B. A.: An improved retrieval of tropospheric nitrogen dioxide from GOME, J. Geophys. Res., 107, art. no.-4437, 2002.

Martin-Reviejo, M. and Wirtz, K.: Is benzene a precursor for secondary organic aerosol?, Environ. Sci. Technol., 39, 1045-1054, 2005.

Mihelcic, D., Holland, F., Hofzumahaus, A., Hoppe, L., Konrad, S., Musgen, P., Patz, H. W., Schafer, H. J., Schmitz, T., Volz-Thomas, A., Bachmann, K., Schlomski, S., Platt, U., Geyer, A., Alicke, B., and Moortgat, G. K.: Peroxy radicals during BERLIOZ at Pabstthum: Measurements, radical budgets and ozone production, J. Geophys. Res., 108(D4), 8254, doi:10.1029/2001JD001014, 2003.

Na, K., Song, C., and Cocker, D. R.: Formation of secondary organic aerosol from its reaction of styrene with ozone in the presence and absence of ammonia and water, Atmos. Environ., 40, 1889-1900, 2006.

Ng, N. L., Kroll, J. H., Chan, A. W. H., Chhabra, P. S., Flagan, R. C., and Seinfeld, J. H.: Secondary organic aerosol formation from m-xylene, toluene, and benzene, Atmos. Chem. Phys., 7, 39093922, 2007, http://www.atmos-chem-phys.net/7/3909/2007/.

Odum, J. R., Hoffmann, T., Bowman, F., Collins, D., Flagan, R. C., and Seinfeld, J. H.: Gas/particle partitioning and secondary organic aerosol yields, Environ. Sci. Technol., 30, 2580-2585, 1996.

Odum, J. R., Jungkamp, T. P. W., Griffin, R. J., Forstner, H. J. L., Flagan, R. C., and Seinfeld, J. H.: Aromatics, reformulated gasoline, and atmospheric organic aerosol formation, Environ. Sci. Technol., 31, 1890-1897, 1997.

Offenberg, J. H., Kleindienst, T. E., Jaoui, M., Lewandowski, M., and Edney, E. O.: Thermal properties of sec- ondary organic aerosols, Geophys. Res. Lett., 33, L03816, doi:10.1029/2005GL024623, 2006.

Olivier, J. G. J., Bouwman, A. F., Van der Maas, C. W. M., Berdowski, J. J. M., Veldt, C., Bloos, J. P. J., Visschedijk, A. J. H., Zandveld, P. Y. J., and Haverlag, J. L.: Description of EDGAR Version 2.0: A set of global emission inventories of greenhous gases and ozone-depleting substances for all anthropogenic and most natural sources on a per country basis and on $1^{\circ} \times 1^{\circ}$ grid, Tech. rep., 1996.

Olivier, J. G. J., Bouwman, A. F., Berdowski, J. J. M., Veldt, C., Bloos, J. P. J., Visschedijk, A. J. H., Van der Maas, C. W. M., and Zandveld, P. Y. J.: Sectoral emission inventories of greenhouse gases for 1990 on a per country basis as well as on $1 \times 1$ degree, Environmental Science \& Policy, 2, 241-264, 1999.

Park, R. J., Jacob, D., Field, B. D., Yantosca, R., and Chin, M.: Natural and transboundary pollution influences on sulfate-nitrateammonium aerosols in the United States: Implications for policy, J. Geophys. Res., 109, D15204, doi:10.1029/2003JD004473, 2004.

Park, R. J., Jacob, D. J., Kumar, N., and Yantosca, R. M.: Regional visibility statistics in the United States: Natural and transboundary pollution influences, and implications for the Regional Haze Rule, Atmos. Environ., 40, 5405-5423, 2006.

Pathak, R. K., Presto, A. A., Lane, T. E., Stanier, C. O., Donahue, N. M., and Pandis, S. N.: Ozonolysis of $\alpha$-pinene: Parameterization of secondary organic aerosol mass fraction, Atmos. Chem. Phys., 7, 3811-3821, 2007, http://www.atmos-chem-phys.net/7/3811/2007/.

Presto, A. A. and Donahue, N. M.: Investigation of $\alpha$-pinene plus ozone secondary organic aerosol formation at low total aerosol mass, Environ. Sci. Technol., 40, 3536-3543, 2006.

Presto, A. A., Hartz, K. E. H., and Donahue, N. M.: Secondary organic aerosol production from terpene ozonolysis. 2. Effect of $\mathrm{NO}_{\mathrm{x}}$ concentration, Environ. Sci. Technol., 39, 7046-7054, 2005.

Pun, B. K. and Seigneur, C.: Investigative modeling of new pathways for secondary organic aerosol formation, Atmos. Chem. Phys. Discuss., 7, 203-245, 2007, http://www.atmos-chem-phys-discuss.net/7/203/2007/.

Robinson, A. L., Donahue, N. M., Shrivastava, M. K., Weitkamp, E. A., Sage, A. M., Grieshop, A. P., Lane, T. E., Pierce, J. R., and Pandis, S. N.: Rethinking organic aerosols: Semivolatile emissions and photochemical aging, Science, 315, 1259-1262, doi:10.1126/science.1133061, 2007.

Simpson, D., Yttri, K. E., Klimont, Z., Kupiainen, K., Caseiro, A., Gelencser, A., Pio, C., Puxbaum, H., and Legrand, M.: Modeling of carbonaceous aerosol over Europe: Analysis of the CARBOSOL and EMEP EC/OC campaigns, J. Geophys. Res., 112, D23S14, doi:10.1029/2006JD008158, 2007.

Stevens, P. S., Mather, J. H., Brune, W. H., Eisele, F., Tanner, D., Jefferson, A., Cantrell, C., Shetter, R., Sewall, S., Fried, A., Henry, B., Williams, E., Baumann, K., Goldan, P., and Kuster, $\mathrm{W}$.: $\mathrm{HO}_{2} / \mathrm{OH}$ and $\mathrm{RO}_{2} / \mathrm{HO}_{2}$ ratios during the Tropospheric $\mathrm{OH}$ Photochemistry Experiment: Measurement and theory, J. Geophys. Res., 102(D5), 6379-6392, doi:10.1029/96JD01704, 1997.

Song, C., Na, K. S., and Cocker, D. R.: Impact of the hydrocarbon to $\mathrm{NO}_{x}$ ratio on secondary organic aerosol formation, Environ. Sci. Technol., 39, 3143-3149, 2005.

Song, C., Na, K. S., Warren, B., Malloy, Q., and Cocker, D. R.: Sec- 
ondary organic aerosol formation from $m$-xylene in the absence of NOx, Environ. Sci. Technol., 41, 7409-7416, 2007.

Song, C., Zaveri, R. A., Alexander, M. L., Thornton, J. A., Madronich, S., Ortega, J. V., Zelenyuk, A., Yu, X., Laskin, A., and Maughan, D. A.: Effect of hydrophobic primary organic aerosols on secondary organic aerosol formation from ozonolysis of $\alpha$-pinZene, Geophys. Res. Lett., 34, L20803, doi:10.1029/2007GL030720.

Sorooshian, A., Ng, N. L., Chan, A. W. H., Feingold, G., Flagan, R. C., and Seinfeld, J. H.: Particulate organic acids and overall water-soluble aerosol composition measurements from the 2006 Gulf of Mexico Atmospheric Composition and Climate Study (GoMACCS), J. Geophys. Res., 112, D13201, doi:10.1029/2007JD008537, 2007.

Surratt, J. D., Kleindienst, T. E., Edney, E. O., Lewandowski, M., Offenberg, J. H., Jaoui, M., and Seinfeld, J. H.: Effect of acidity on secondary organic aerosol formation from isoprene, Environ. Sci. Technol., 41, 5363-5369, 2007.

Tsigaridis, K. and Kanakidou, M.: Global modelling of secondary organic aerosol in the troposphere: A sensitivity analysis, Atmos. Chem. Phys., 3, 1849-1869, 2003,

http://www.atmos-chem-phys.net/3/1849/2003/.

Tsigaridis, K. and Kanakidou, M.: Secondary organic aerosol importance in the future atmosphere, Atmos. Environ., 41, 46824692, 2007.

Tsigaridis, K., Krol, M., Dentener, F. J., Balkanski, Y., Lathiere, J., Metzger, S., Hauglustaine, D. A., and Kanakidou, M.: Change in global aerosol composition since preindustrial times, Atmos. Chem. Phys., 6, 5143-5162, 2006,

http://www.atmos-chem-phys.net/6/5143/2006/.

Turpin, B. J. and Lim, H. J.: Species contributions to $\mathrm{PM}_{2.5}$ mass concentrations: Revisiting common assumptions for estimating organic mass, Aerosol. Sci. Tech., 35, 602-610, 2001.

van der Werf, G. R., Randerson, J. T., Giglio, L., Collatz, G. J., Kasibhatla, P. S., and Arellano, A. F.: Interannual variability in global biomass burning emissions from 1997 to 2004, Atmos. Chem. Phys., 6, 3423-3441, 2006,

http://www.atmos-chem-phys.net/6/3423/2006/.

van Donkelaar, A., Martin, R. V., Park, R. J., Heald, C. L., Fu, T.M., Liao, H., and Guenther, A.: Model evidence for a significant source of secondary organic aerosol from isoprene, Atmos. Environ., 41, 1267-1274, 2007.

van Noije, T. P. C., Eskes, H. J., Dentener, F. J., Stevenson, D. S., Ellingsen, K., Schultz, M. G., Wild, O., Amann, M., Atherton, C. S., Bergmann, D. J., Bey, I., Boersma, K. F., Butler, T., Cofala, J., Drevet, J., Fiore, A. M., Gauss, M., Hauglustaine, D. A., Horowitz, L. W., Isaksen, I. S. A., Krol, M. C., Lamarque, J. F., Lawrence, M. G., Martin, R. V., Montanaro, V., Muller, J. F., Pitari, G., Prather, M. J., Pyle, J. A., Richter, A., Rodriguez, J. M., Savage, N. H., Strahan, S. E., Sudo, K., Szopa, S., and van Roozendael, M.: Multi-model ensemble simulations of tropospheric $\mathrm{NO}_{2}$ compared with GOME retrievals for the year 2000 , Atmos. Chem. Phys., 6, 2943-2979, 2006,

http://www.atmos-chem-phys.net/6/2943/2006/.

Volkamer, R., Klotz, B., Barnes, I., Imamura, T., Wirtz, K., Washida, N., Becker, K. H., and Platt, U.: OH-initiated oxidation of benzene - Part I. Phenol formation under atmospheric conditions, Phys. Chem. Phys., 4, 1598-1610, 2002.

Volkamer, R., Uecker, J., Wirtz, K. and Platt, U.: OH-Radical initiated oxidation of BTXM: Formation and atmospheric fate of phenol-type compounds in the presence of $\mathrm{NO}_{\mathrm{X}}$, proceedings from the EUROTRAC-2 Symposium 2002 "Transport and Chemical Transformation in the Troposphere", edited by: P. M. Midgley and M. Reuther, Margraf Verlag, Weikersheim, 2002.

Volkamer, R., Jimenez, J. L., San Martini, F., Dzepina, K., Zhang, Q., Salcedo, D., Molina, L. T., Worsnop, D. R., and Molina, M. J.: Secondary organic aerosol formation from anthropogenic air pollution: Rapid and higher than expected, Geophys. Res. Lett., 33, L17811, doi:10.1029/2006GL02689, 2006.

Volkamer, R., San Martini, F., Molina, L. T., Salcedo, D., Jimenez, J. L., and Molina, M. J.: A missing sink for gas-phase glyoxal in Mexico City: Formation of secondary organic aerosol, Geophys. Res. Lett., 34, 10.1029/2007GL030752, doi:L19807, 2007.

Wang, Y. H., Jacob, D. J., and Logan, J. A.: Global simulation of tropospheric $\mathrm{O}_{3}-\mathrm{NO}_{x}$-hydrocarbon chemistry 1 . Model formulation, J. Geophys. Res., 103, 10713-10 725, 1998.

Wang, Y. X., McElroy, M. B., Martin, R. V., Streets, D. G., Zhang, Q., and Fu, T. M.: Seasonal variability of $\mathrm{NO}_{x}$ emissions over east China constrained by satellite observations: Implications for combustion and microbial sources, J. Geophys. Res., 112, D06301, doi:10.1029/2006JD007538, 2007.

Warneke, C., McKeen, S. A., de Gouw, J. A., Goldan, P. D., Kuster, W. C., Holloway, J. S., Williams, E. J., Lerner, B. M., Parrish, D. D., Trainer, M., Fehsenfeld, F. C., Kato, S., Atlas, E. L., Baker, A., and Blake, D. R.: Determination of urban volatile organic compound emission ratios and comparison with an emissions database, J. Geophys. Res., 112, D10S47, doi:10.1029/2006JD007930, 2007.

Weber, R. J., Sullivan, A. P., Peltier, R., Russel, A. G., Yan, B., Zheng, M., de Gouw, J. A., Warneke, C., Brock, C. A., Holloway, J., Atlas, E. L., and Edgerton, E.: A study of secondary organic aerosol formation in the anthropogenicinfluenced southeastern United States, J. Geophys. Res., 112, D13302, doi:10.1029/2007JD008408, 2007.

Wesely, M. L.: Parameterization of Surface Resistances to Gaseous Dry Deposition in Regional-Scale Numerical-Models, Atmos. Environ., 23, 1293-1304, 1989.

Zhang, Y., Huang, J.-P., Henze, D. K., and Seinfeld, J. H.: The role of isoprene in secondary organic aerosol formation on a regional scale, J. Geophys. Res., 112, D20207, doi:10.1029/2007JD008675, 2007.

Zhang, Q., Jimenez, J. L., Canagaratna, M. R., Allan, J. D., Coe, H., Ulbrich, I., Alfarra, M. R., Takami, A., Middlebrook, A. M., Sun, Y. L., Dzepina, K., Dunlea, E., Docherty, K., DeCarlo, P. F., Salcedo, D., Onasch, T. B., Jayne, J. T., Miyoshi, T., Shimono, A., Hatakeyama, S., Takegawa, N., Kondo, Y., Schneider, J., Drewnick, F., Borrmann, S., Weimer, S., Demerjian, K., Williams, P., Bower, K., Bahreini, R., Cottrel, L., Griffin, R. J., Rautianen, J., Sun, J. Y., Zhang, Y. M., and Worsnop, D. R.: Ubiquity and dominance of oxygentated species in organic aerosols in anthropogenically-influenced Northern Hemisphere midlatitudes., Geophys. Res. Lett., 34, L13801, doi:10.1029/2007GLO29979, 2007.

Zhao, J., Zhang, R. Y., Misawa, K., and Shibuya, K.: Experimental product study of the $\mathrm{OH}$-initiated oxidation of m-xylene, J. Photoch. Photobio. A, 176, 199-207, 2005. 